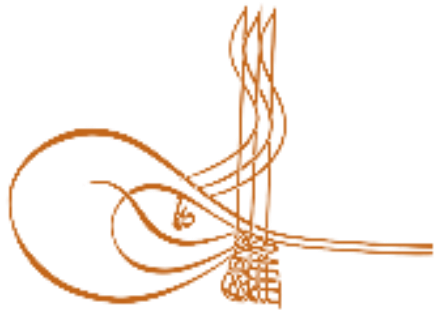

www.turkishstudies.net/social
Turkish Studies - Social Sciences

eISSN: $2667-5617$

Research Article / Araştırma Makalesi

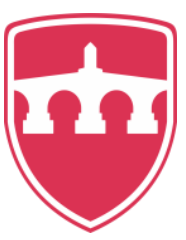

INTERNATIONAL

BALKAN

UNIVERSITY

Sponsored by IBU

\title{
Babürlü Hanedanlığının Son Anıtsal Türbesi Bibi Ka Makbere (Rabia-ud Devrani Türbesi\&Mini Tac Mahal)
}

\author{
The Last Monumental Tomb of Mughal Dynasty Bibi Ka Maqbara (The Tomb of Rabia-Ud Durani \\ \&Mini Taj Mahal)
}

\author{
Fadime Özler ${ }^{*}$
}

\begin{abstract}
Mughals reigned in Indian subcontinent that is many areas including today's India, Pakistan and Bangladesh for nearly two centuries, and they built important monumental buildings in these large areas. In their period, unique examples were produced especially in tomb architecture. The Tomb of Taj Mahal in the city of Agra, which Shah Jahan had built for his wife Mumtaz Mahal (1631-48), perhaps made the tomb architecture unattainable, and carried it to its last stage not only in Mughal period but also in the framework of Turkish-Islamic period. Taj Mahal can be an example for many tombs built after it, and it left behind many monumental tombs built before and after it. Taj Mahal Tomb was also almost a prototype for Bibi Ka Maqbara, which is the subject of the research. Bibi Ka Maqbara had been built (1651-1661) in Aurangabad city of India by Muhammad Azam Shah, the son of Aurangzeb, for his mother Dilras Banu Begum. The tomb is usually compared with Taj Mahal, the tomb of Aurangzeb's mother, Mumtaz Mahal, and therefore is called as "The Taj of Deccan or Mini Taj Mahal." Both tombs had been built for the favorite wives of the rulers of the related periods. On the inscription located over the main entrance gate of the construction, it is stated that the architect of the building was Ataullah, the son of Master Ahmad Lahauri, one of the architects of Taj Mahal, and it was designed by Hanspat Rai, one of the engineers of the period. The construction also draws attention with its Charbagh-styled garden. The tomb is located on a square platform, and there is a minaret with two balconies on each corner of the platform. The inside plan of the tomb is square and the outside is octagon, and it is covered with dome. The tomb was built with a material, a mixture of limestone and gypsum, and its platform and dome is white marble. The ornamental design of the tomb is also at great importance as well as its architecture and material. It is seen that the intense botanical ornaments of Taj Mahal, which was created by a high level of relief and carving techniques, were employed here with the same intensity but by using a different material, on the limestone and gypsum instead of white marble. While the first monumental tomb of Mughal period is Humayun's Tomb in Delhi, the last one is Bibi Ka Maqbara. In this research, the similarities and differences between the Tomb and Islamic and Turkish tomb architecture and its place among Mughal tomb examples will be evaluated, and also both architectural features and ornamental design of the tomb will be handled.
\end{abstract}

\footnotetext{
* Arş. Gör., Erciyes Üniversitesi Edebiyat Fakültesi, Sanat Tarihi Bölümü Res. Asst., Erciyes University, Faculty of Letters, Department of Art History ORCID 0000-0002-9241-9874

fadimeozler@gmail.com

Cite as/ Atıf: Özler, F. (2020). Babürlü hanedanlığının son anıtsal türbesi bibi ka makbere (Rabia-ud Devrani türbesi\&mini Tac Mahal), Turkish Studies - Social, 15(1), 489-509. https://dx.doi.org/10.29228/TurkishStudies.40157

Received/Geliș: 13 December/Aralık 2020

Accepted/Kabul: 25 February/Şubat 2020

Checked by plagiarism software

Copyright $(\mathrm{C}$ INTAC LTD, Turkey

Published/Yayın: 29 February/Şubat 2020

CC BY-NC 4.0
} 
Structured Abstract: Like several states founded in India, Mughals also made use of the rich cultural environment of this region in the best manner, and they achieved to reveal significant architectural works with their own deep-rooted heritage and powerful architectural pleasure. Especially in tomb architecture, they built tombs in monumental scale. This process starting with Humayun's Tomb in Delhi continued by improving and changing until Bibi Ka Maqbara in the city of Aurangabad. Humayun's Tomb has been defined as "a spectacular milestone in the improvement of Mughal architectural style." The fact that the tombs were built in a monumental scale during the Mughal period made it possible to consider the tombs as the prestigious works of this period. The most monumental and original examples of tomb architecture in the Turkish-Islamic world were built in Mughals period.

Bibi Ka Maqbara, in other words, the Tomb of Rabia-Ud Durani, is located in the northwest of Aurangabad city in Maharashtra, south of India. The tomb was built at a point overlooking the city at the highest place of the city, on the bank of Kham River (today it flows through the city) in the period it was built. Bibi Ka Maqbara was also built at the heart of the garden in charbagh-style surrounded by high walls, in accordance with classical Mughal garden design. Garden arrangement was divided into four equal parts by water channels. In the middle of each wall edge of the square garden there are monumental entrance buildings, but the entrance to the garden is only ensured through the entrance building located in the south. In addition to the tomb, there is also a mansion (baradari), which is used as a museum today, and a mosque. While the tomb and the mosque are located on the same platform, the mansion was built single-storey in the middle of the north wall edge of the garden.

The subject of the research, Bibi Ka Maqbara, which is the late monumental tomb of the Mughal period and the last monumental tomb of the dynasty has been investigated by many researchers but could not find the exact place it deserves in the literature. In general, researchers have compared Bibi Ka Maqbara with The Taj Mahal, and they have not handled the architectural and ornamental characteristics of the work in detail. If Bibi Ka Maqbara had been built before The Taj Mahal, perhaps it would have been seen as an essential construction necessary to be investigated for many researchers investigating the Taj Mahal. Undoubtedly, the reason why the building was subjected to such criticism is that it was overshadowed by the Taj Mahal's magnificence in plan, architecture, material, decoration and monumentality as well as being built after the Taj Mahal. In the evaluation chapter of this study, it is emphasized why the Taj Mahal and Bibi Ka Maqbara have been compared, and similarities and differences of the two constructions are tried to be revealed.

The tombs of Mughal rulers are located in the important cities that were the capitals of the state such as Agra, Delhi, Lahore and Aurangabad. In Mughals, the tombs of the women in the dynasty were built in important cities of the state in monumental scale like their husbands' and children's. The monumental tombs, on the other hand, have been subjected to criticism and comparisons by many researchers, perhaps more than ever at the time they were built. Among them, unfortunately the Taj Mahal, built for Mumtaz Mahal, Aurangzeb's mother and Bibi Ka Maqbara, built for his wife Dilras Banu Begum, have always been compared. However, both buildings were built for the important women sultans of the period and exist as significant architectural works of the city they are in today, as they were in the period they were built. The Tomb of Dilras Banu Begum is called in the region as Mini Taj Mahal and The Taj of Deccan due to these similarity ascriptions as well as the common denotations of the Tomb of Rabia-Ud Durani and Bibi Ka Maqbara. Ataullah, the architecture of Bibi Ka Maqbara is the son of Ahmad Lahauri, one of the master builders of the Taj Mahal (Michell and Zebrowski, 2008: 110), and this relationship is an evidence of that comparing these two architectures that much should not be surprising. It will be more accurate to evaluate the tomb not as a copy of the Taj Mahal, but as a developmental stage of the tomb architecture in Mughal period and a different version of Taj Mahal. In fact, the Taj Mahal is the prototype of the tomb. In addition, the tomb does not reveal similarities with the Taj Mahal only, and it is seen that there are pretty close similarities with Humayun's Tomb architecturally. It will be more sound and appropriate to associate that it was impossible for Bibi Ka Maqbara not to be affected by the Taj Mahal instead of the misperception of that it is a copy of the Taj Mahal. However, although the building has general Mughal characteristics with its plan and architecture, it has significant differences in terms of proportion and design. The burial chamber of the tomb is as unique as it cannot be compared with any tomb examples. In other Mughal dynasty tombs, there is the symbolic coffin on the ground floor where the burial chamber is located, and just at align of this ground floor, downstairs, there is the burial floor where the actual coffin is located. However, in this tomb, there is only one coffin, and the area where the symbolic coffin should have been located in the main space of the ground floor was left empty, and when one looks down from here, the actual coffin on the downstairs is seen. What distinguishes the tomb from other 
Mughal and Turkish-Islamic tomb examples is that the visitors see the actual coffin when they look down from the ground floor.

Consequently, the tomb is a quite successful construction with both the material and architecture and ornaments in spite of the limited possibilities of the state, close to the date that Mughal Period would end. The fact that the building still stands upright despite the climatic conditions of the region shows that the material was used in good quality considering the conditions of the period. Bibi Ka Maqbara is a milestone in architectural aesthetics. Although it is thought to be disproportional when it is evaluated with its architectural characteristics and the plan, the construction is quite unique and also elegant and aesthetic in terms of its ornamental characteristics and design.

Keywords: Art History 1, Aurangabad 2, Mughal 3, Tomb 4, Bibi Ka Maqbara 5.

Öz: Babürlüler yaklaşık iki asır Hint alt kıtasında; günümüzde Hindistan, Pakistan ve Bangladeş'in de içerisinde bulunduğu birçok bölgede hüküm sürmüş ve bu geniş coğrafyalarda önemli anıtsal eserler inşa etmişlerdir. $\mathrm{Bu}$ dönemde özellikle türbe mimarisinde eşsiz örnekler ortaya konulmuştur. Şah Cihan'ın eşi Mümtaz Mahal için (1631-48) yaptırmış olduğu Agra şehrindeki Tac Mahal Türbesi belki de türbe mimarisini yalnız Babürlü dönemi içinde değil, Türk-İ̀slam dönemi çerçevesinde de erişilmez kılıp son safhasına ulaştırmıştır. Tac Mahal, kendisinden sonra yapılan birçok türbeye örnek teşkil etmiş olabileceği gibi öncesinde ve sonrasında inşa edilen birçok anıtsal mezarı gerisinde bırakmıştır. Araştırma konusunu oluşturan Bibi Ka Makbere için de Tac Mahal Türbesi adeta bir prototip oluşturmuştur. Bibi Ka Makbere; Babürlü hükümdarlarından Evrengzib'in oğlu Muhammed Azam Şah tarafindan (1651-1661) annesi Dilras Banu Begüm için Hindistan'ın Evrengabad şehrinde yaptırılmıştır. Türbe; hükümdar Evrengzeb'in validesi olan Mümtaz Mahal'in türbesi Tac Mahal ile genel olarak benzetilmekte ve bundan dolayı "Dekkan'ın Tacı ya da Mini Tac Mahal” adı ile anılmaktadır. Her iki mezar yapısı da dönemin hükümdarlarının gözde eşleri için yaptırılmıştır. Yapının ana giriş kapısında bulunan kitabesinde; mimarının Tac Mahal'in mimarlarından olan Üstad Ahmed Lahori'nin oğlu Ataullah olduğu ve dönemin mühendislerinden Hanspat Rai tarafindan tasarlandığı belirtilmektedir. Yapı, Babürlü Mimarisi'nin karakteristik özelliği olan çarbağ düzeninde bahçe tasarımı ile de dikkat çekmektedir. Kare bir platform üzerinde yer alan ve platformunun her bir köşesinde ikişer şerefeli minareleri bulunan türbe; dışarıdan kare, içeriden sekizgen planlı olup üzeri kubbe ile örtülüdür. Beyaz kireç taşı ve alçı karışımı bir malzeme ile yapılmış olan türbenin; platformu ve kubbesi beyaz mermerden oluşmaktadır. Türbenin mimari ve malzemesi yanında süsleme programı da oldukça önemlidir. Tac Mahal'in yüksek kabartma ve oyma tekniği ile oluşturulan yoğun bitkisel süslemelerinin burada benzer bir şekilde, aynı yoğunlukta ancak farklı bir malzeme kullanılarak beyaz mermer yerine kireç taşı ve alçı üzerine işlendiği görülmektedir. Babürlü döneminin ilk anıtsal türbesi Delhi' deki Hümayun Türbesi iken son anıtsal türbesi Bibi Ka Makbere'dir. Bu araştırmada türbenin Babürlü türbe örnekleri içerisindeki yeri ile birlikte İslam ve Türk türbe mimarisindeki benzerlik ve farklılıkları değerlendirilmeye çalışılırken aynı zamanda türbenin hem mimari özellikleri hem de süsleme programı üzerinde durulacaktır.

Anahtar Kelimeler: Sanat Tarihi 1, Evrengabad 2, Babürlü 3, Türbe 4, Bibi Ka Makbere 5.

\section{Giriş}

Toprak anlamındaki Arapça "türb” kökünden gelen türbe kelimesi, mezar üzerine kurulan binalara âlem olmuştur. Ancak, bu yapılar, kitabelerinde ve araştırmalarda yalnızca bu isimle anılmamakta, bununla birlikte, kubbe, künbed, meşhed, makbere veya ravza gibi değişik adlarla da ifade edilmektedirler. Türbe, İslam dünyasında Türkler tarafindan yaygınlaştırılan bir yapı tipidir (Önkal, 2015: 13). İslam türbe mimarlığının hayranlık uyandıran ve sıra dışı örnekleri, Hind coğrafyasında ortaya çıkmıştır. Günümüzün önemli şehirlerinden metruk yerleşim birimlerine ve kırsala kadar Hindistan'ın pekçok bölgesinde, ölümün anıtsallaştırıldığ1 bu mezar yapılarını görmek mümkündür (Palalı, 2013: 154). Babürlüler; Hint alt kıtası denilen günümüzde Hindistan, Pakistan ve Bangledeș'i de içerisine alan bu geniș coğrafyada hâkimiyet sağlamıș ve aynı zamanda bu bölgelerde önemli imar faaliyetlerinde bulunmuşlardır. Babürlüler özellikle türbe mimarisinde 
anıtsal örnekler ortaya koymuşlardır. Fergusson, Hint Mimarlık Tarihi kitabında Babürlü dönemi türbelerinden şu şekilde bahsetmektedir:
"Onlar mezarlarını kendileri inșa etmişlerdir. Bu mezarlar, kendileri hayattayken onların ve arkadaşlarının zevklerine, beğenilerine hizmet eden yerler olarak kullanılmış; onlar öldükten sonra ise ölmüss bedenleri için kutsal dinginliğe sahip yerler haline dönüssmüşürr. Bu binaların inşast için olağan süreç şu şekildedir; hükümdar veya soylu kişi kendisine türbe yaptırmak ister ve türbeyi şehir duvarları dışında bir mazgall yüksek duvarl bahçeyle çevreler, bir veya iki görkemli giriş kapısı yaptırır, bunun merkezine kare veya sekizgen bir yapı inşa ettirip bir kubbeyle taçlandırır; daha görkemli örneklerde ise dört kenardaki veya kössedeki odalar daha küçük kubbeli çattlıdır, diğer dört kubbe ise girişlerde yer almaktadır. Bu yapı, genellikle, dört geniş patikaya açılan kare, yüksek bir terasa konumlanmaktadir, mermer kapl kanallar çeşmelerle süslenmektedir; köşeli boşluklar ise selvilerle, yeşil bitkilerle ve meyve ağaçlarlyla kaplanmaktadır. Bu şekilde güzel bahçeler oluşturmak doğuya özgü bir karakterdir. Baninin hayatta olduğu süre boyunca, merkezdeki yapı "Baradari (Barrah Durrie)" veya "yazlık köşk-eğlenceli salon” olarak adlandırllmakta ve baninin kendisi veya arkadaşları tarafindan eğlence, dinlenme, ziyafet alanı olarak kullanılmaktadır. Ölümüyle kaderi değişir - baninin cesedi merkezdeki kubbenin altına gömülür. Bazen en sevdiği eşi de kendisinin yanına gömülür; ancak ailesi ve akrabaları daha slklkkla tamamlayıcı kubbelerin altına gömülü̈r. Bir kere mezar alanı olarak kullanıldıktan sonra, duvarlardan festival neşesi sesleri bir daha asla yükselmez. Neşenin ve festival havasinın yerini mükemmel bir sessizlik alır. Etrafi çevreleyen objelerin güzelliği, mekânın huzuruyla birleşir ve kutsalliğl, münasipliği kadar zarif bir etki yaratır" (Fergusson, 1910: 575).

Araştırmanın konusunu oluşturan, Babürlülerin geç dönemine ait ve hanedanlığın son anıtsal türbesi olan Bibi Ka Makbere; birçok araştırmacı tarafından incelenmiş ancak literatürde tam olarak hak ettiği yeri bulamamıştır. Genel olarak araştırmacılar yapmış oldukları çalışmalarda Bibi Ka Makbere'yi Tac Mahal ile mukayese etmiş ancak eserin mimari ve süsleme özelliklerini ayrıntılı bir şekilde ele almamışlardır. Bunun en önemli sebebi eserin ne yazık ki Tac Mahal'in mimari, süsleme ve anıtsallığındaki ihtişamının gölgesinde kalıyor olmasıdır. Bibi Ka Makbere Tac Mahal'den önce yapılmış olsa belki de Tac Mahal'i araştıran birçok araştırmacı için Bibi Ka Makbere incelenmesi gereken zaruri bir yapı olarak görülecekti. Şüphesiz yapının bu kadar eleştiriye maruz kalması Tac Mahal'den sonra inşa edilmiş gerek plan gerek süsleme gerekse malzeme açısından Tac Mahal'in gerisinde kalmış olmasıdır. Bu çalışmanın değerlendirme bölümünde; Tac Mahal ile Bibi Ka Makbere'nin neden mukayese edildiği üzerinde de durulmuş her iki yapı arasındaki benzer ve farklı yönler ortaya konulmaya çalışılmıştır (Foto: 1-2). 

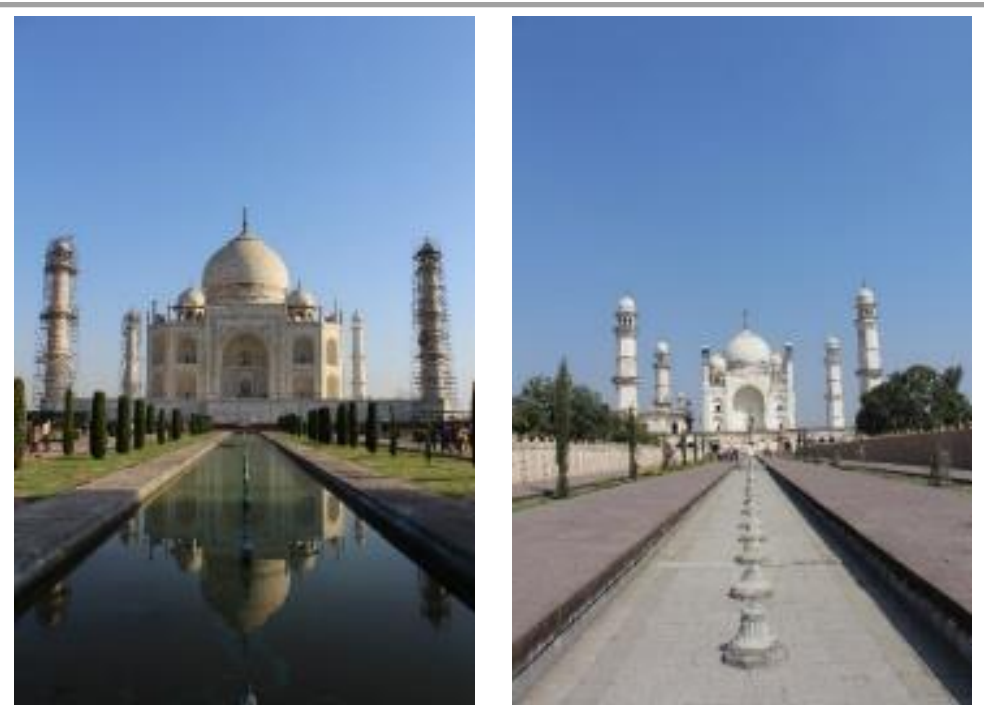

Fotoğraf: 1-2 Tac Mahal Genel Görünüşü, Bibi Ka Makbere Genel Görünüşü (Özler,2017)

\section{Bibi Ka Makbere}

Bibi Ka Makbere yani Rabia-ud Devrani Türbesi, Hindistan'ın güneyinde Maharaştra'daki Evrengabad şehrinin kuzeybatısında bulunmaktadır. Türbe, kentin en yüksek yerinde kente hâkim bir noktada, inşa edildiği dönemde Kham nehrinin kıyısında (günümüzde şehrin içinden akmakta) inşa edilmiștir. Bibi Ka Makbere; Babürlüler'in altıncı hükümdarı, Hindistan tarihçileri tarafından daha çok Alemgir ünvanıyla anılan (Türk Diyanet Vakfı, 1988-2013: 537-39) Muhammed Muhyiddin Evrengzib döneminde inşa edilmiştir. Evrengzib, Babürlülerin altı büyük hükümdarının sonuncusudur (Türk Diyanet Vakfı, 1988-2013: 402). Sultan Evrengzib'in keza yarım yüzyıllık iktidarı Hindistan'ın göremediği fütuhat, cihangirlik, saltanat ve ihtişam devri olmuştur (Galib ve Gömeç, 2013: 109). Bu dönemde bilindiği üzere çok fazla eser ortaya konulamadığı kanaati aslında yanlıştır. Çünkü başta Lahor'da olmak üzere Agra'da, Delhi'de ve Evrengabad'da birçok önemli mimari eser inşa edilmiştir. Evrengabad'daki Bibi Ka Makbere'de Evrengzib döneminde inşa edilen en önemli eserlerden biridir. Bibi Ka Makbere; Evrengzib'in eşi Dilras Banu Begüm adına 1651-61 yılları arasında oğulları Muhammed Azam Şah tarafından yaptırılmıştır (Michell, 2007: 281). Begüm veya Bibi olarak bilinen aynı zamanda Rabia-ud-Devrani (Çağının Rabia'sı) olarak anılan Dilras Banu Begüm; babası İranlı Mirza Badi-uz-Zaman Safavi (Şah İsmail'in soyundan, Şah Nafiz Han Safavi) (Robinson, 2007: 157), annesi Nevruz Banu Begüm 'dür. 1637'de Evrengzib ile evlenmiş ve 5 çocukları dünyaya gelmiştir. Dilras Banu Begüm 5. çocuklarının doğumundan kısa bir süre sonra 1657 yılında vefat etmiştir. Yapının ana giriş kapısında bulunan kitabesinde; mimarının Tac Mahal'in mimarlarından olan Üstad Ahmed Lahori'nin oğlu Ataullah olduğu ve dönemin mühendislerinden Hanspat Rai tarafından tasarlandığ 1 belirtilmektedir (Parodi, 1988: 376).

\section{Mimari ve Süsleme Özellikleri}

Diğer Babürlü türbe örneklerinde olduğu gibi Bibi Ka Makbere de klasik Babürlü bahçe tasarımına uygun, çar bağ düzeninde, yüksek duvarlarla çevrili bahçenin tam ortasına inşa edilmiştir. Bahçe düzenlemesi su kanalları ile dört eşit parçaya bölünmüştür. Kare planlı bahçe duvarının her bir kenar ortasında simetriği sağlamak için anıtsal giriş bina düzenlemeleri mevcut olup, sadece güneyde yer alan giriş bina düzenlemesinden bahçeye geçiş sağlanmaktadır. Bahçede türbe ile birlikte cami ve günümüzde müze olarak kullanılan bir de köşk (baradari) bulunmaktadır. Türbe ile cami aynı platform üzerinde yer alırken, köşk türbenin kuzeyinde bahçenin kuzey duvarının kenar ortasında tek katlı olarak inşa edilmiştir (Foto: 3-4). 


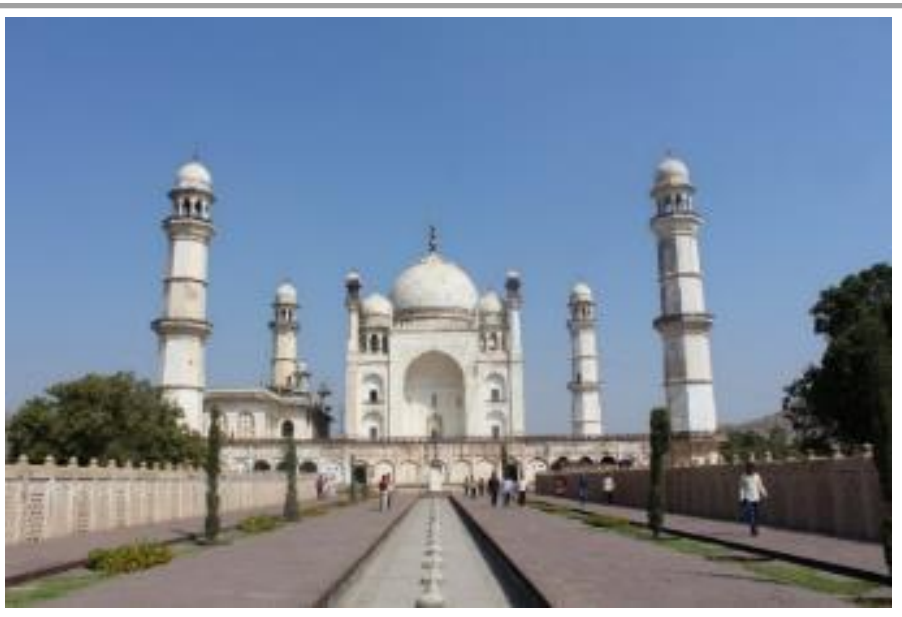

Fotoğraf: 3 Bibi Ka Makbere Türbesi ve Camisi Genel Cephe Görünüşü (Özler,2017)

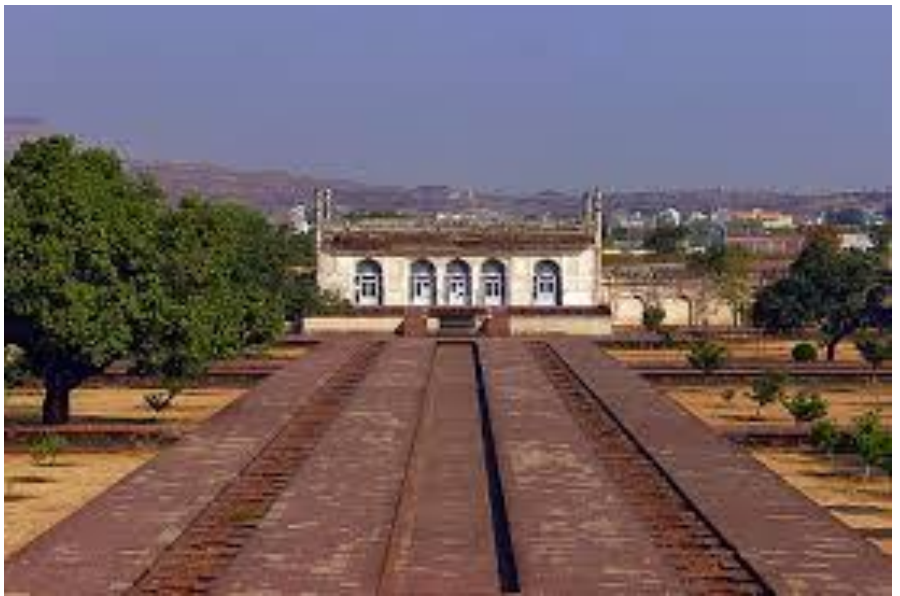

Fotoğraf: 4 Bibi Ka Makbere Baradari- Köşk Genel Cephe Görünüşü

(https://www.istockphoto.com/tr/foto\%C4\%9Fraf/baradari-bibi-ka-maqbara-aurangabad-hindistangm1026562800-275284847)

Türbenin yer aldığı bahçeye tek girişi sağlayan güney giriş bina düzenlemesi çokgen planlı olup alçı ve kireç taşı karışımından oluşan bir malzeme ile yapılmıştır. Yapının iç mekân süslemeleri özenle oluşturulmuş alçı üzerine renkli sıvalarla oluşturulmuş bitkisel, geometrik ve nesnel süslemeler yer almaktadır. Ayrıca yapının süslemeleri kadar ana mekânı örten kubbesinin ve iç mekândaki alanları örtmek için kullanılan tonozların yüzeylerinde kabartma ile oluşturulmuş ağ geçme şeklinde geometrik süslemeleri de oldukça dikkat çekicidir. Burada bulunan süslemeler Agra'daki İtimat-ud Devle Türbesi'ndeki ve Lahor'daki Padişah Camisi'nde yer alan süslemelere çok benzemektedir. Giriş bina düzenlemesi üzerinde bulunan bitkisel motifler arasında; zambak, nergis, palmet, rumi, lotus, hatailer vardır. Her bir niş içerisinde (China-Khana; Babürlü mimarlığında yapı üzerinde dekoratif amaçlı yapılan üzeri çoğu zaman yoğun süslemelere sahip sağır nişlere verilen ad) altlığı bulunan vazolar bulunmaktadır. Kapı kemer alınlığı üzerinde ise kıvrık dallar arasında palmet, zambak, karanfil, gül, gelincik çiçeği yer alırken süsleme kompozisyonu Tac Mahal'in Dervaza-i Ravza giriş bina düzenlemesi ve Tac Mahal Türbesi'nin taç kapı kemer alınlığındaki süslemeleri ile yakın benzerlik göstermektedir (Foto: 5-6-7-8). 

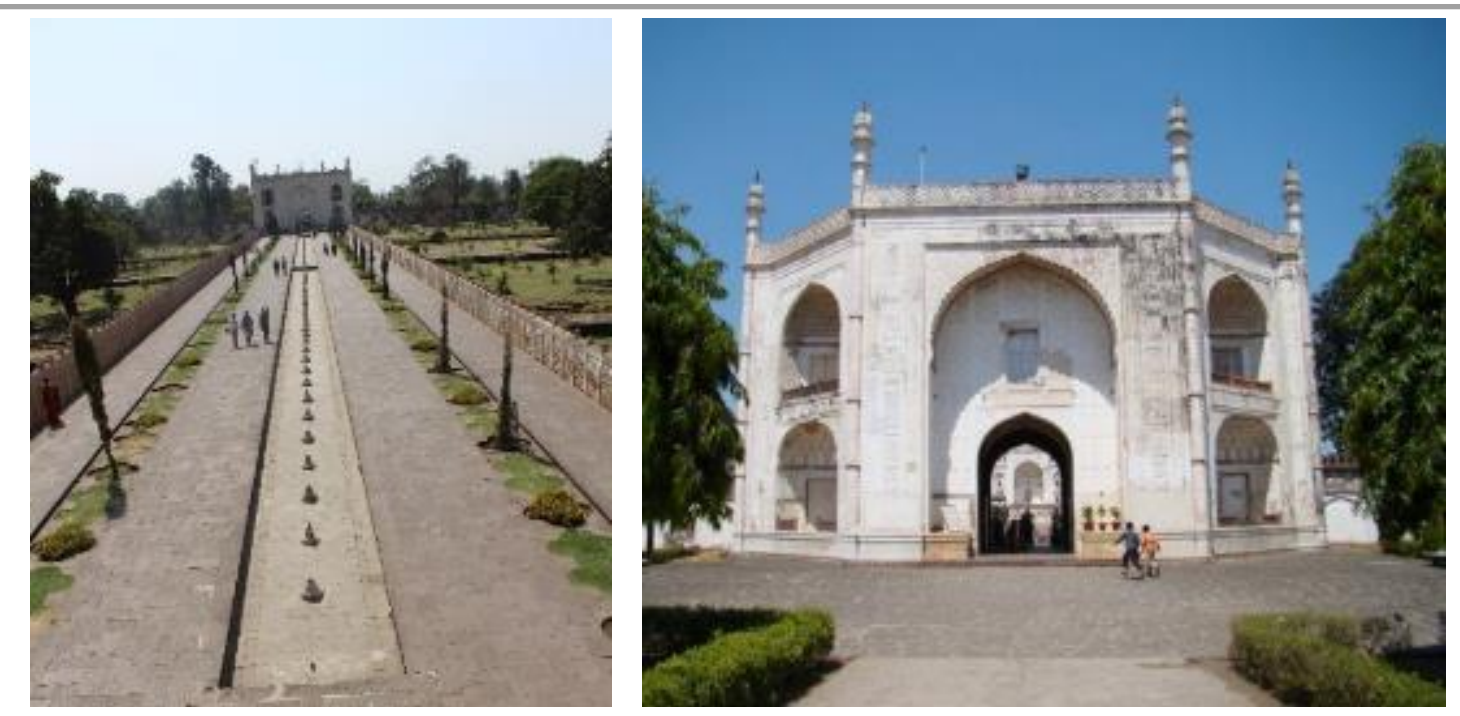

Fotoğraf: 5-6 Bibi Ka Makbere Giriş Bina Düzenlemesi Genel Cephe Görünüşü (Özler,2017), https://talesalongtheway.com/2016/05/18/surprise-taj-mahal-2/
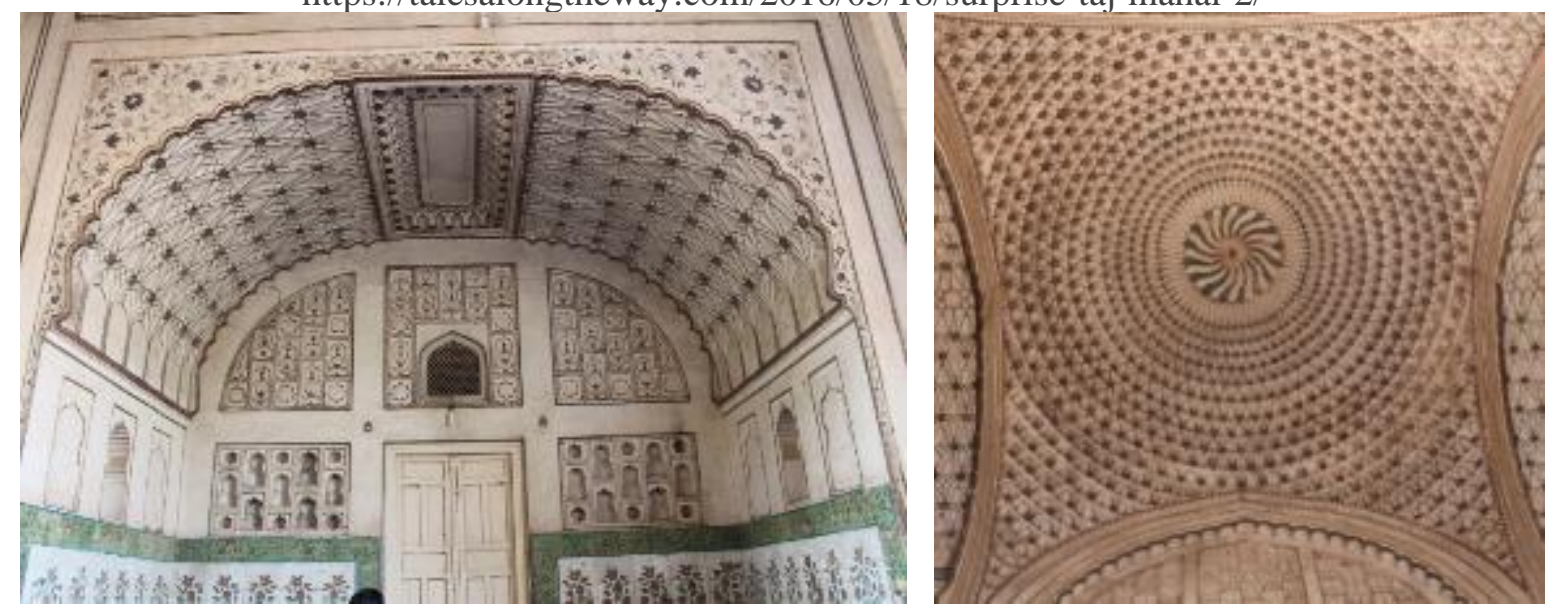

Fotoğraf: 7-8 Bibi Ka Makbere Giriş Bina Düzenlemesi Genel Cephe Görünüşü (Özler,2017)

Güney giriş bina düzenlemesinden yani ana kapıdan geçince dar bir geçitle türbeye kadar, merkezde bir dizi çeşmeye sahip uzun bir havuz bulunmaktadır. Yapıyı bahçeden de soyutlayan mermerden sivri kemerli geometrik desenlerle oluşturulan delikişi (jali) duvarlarla çevrilidir. Türbe; köşelerinde dört minaresi bulunan, kare şeklinde bir platform üzerinde inşa edilmiştir. Kare planlı platformun her bir kenarında 19 kemer gözünden oluşan hücreleri bulunmaktadır. Bu kemer gözlerinin her cephede 5'i açık diğerleri sağır şekildedir. Türbeye Kuzey-Güney ve Doğudan olmak üzere üç cepheden erişim sağlanmakta ve merdivenlerle üst kata çıkılmaktadır. Platform üzerinde yer alan kemerler çok dilimli olup, üzerlerinde yer alan dikdörtgen şeklindeki panolar içerisinde kenar uçları sivri şekilde sonlanan çok dilimli köşebentler bulunmaktadır. Kemerlerin alınlıkları ve üzerlerinde yer alan bu dikdörtgen panoların yüzeyleri bütün platform genelinde sade olup, yüzeylerinde herhangi bir bezeme kalıntısı bulunmaması nedeniyle yapıldığı dönemde de süslemenin olmadığı tahmin edilmektedir. Platformun Kuzey-Güney ve Doğu cephelerinin kenar ortalarında dikdörtgen havuzları bulunmaktadır. Batı cephesinde caminin girişi bulunduğundan dolayı burada havuz yer almamaktadır (Foto: 9-10). 

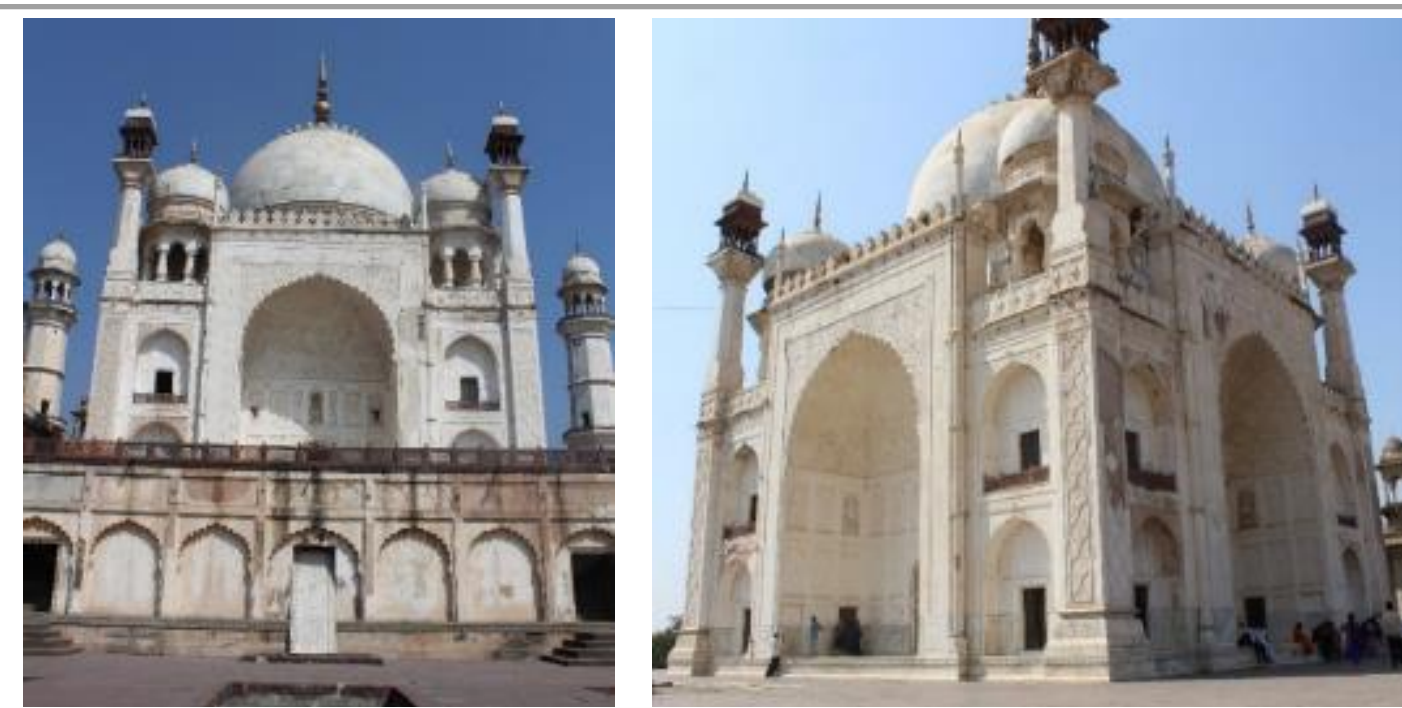

Foto: 9-10 Bibi Ka Makbere (Özler,2017)

Evrengabad şehrinde Babürlü döneminin bir simgesi haline gelen ve dönemin en anıtsal yapısı olan Bibi Ka Makbere; kare planlı yaklaşık 4,5 metre yüksekliğinde bir platformun tam merkezinde, dört cephesinde yaklaşık olarak 7 metre yüksekliğinde ve 6 metre eninde anıtsal eyvan düzenlemesine sahip taç kapıları ile çevrili olup üzeri beyaz mermer kubbeyle örtülü dışarıdan kare içeriden sekizgen bir plana sahiptir. Ana mekâna açılan köşe mekânlarının üzerine ise içeriden küçük kubbelerle örtülmüş dışarıdan kubbeli çatriler yerleştirilmiştir. Yapının ana mekânını örten kubbesi ve çatrilerin üzerinde yer alan kubbeler oldukça yüksek tutulmuş mukarnaslı kasnağa sahiptir. Yap1 üzerinde yer alan kubbelerin soğanvari formları belirgindir. Türbenin yapı bünyesine bitişik olmayan, aynı Agra'da bulunan Tac Mahal Türbesi'nde olduğu gibi platformun her bir köşesinde yer alan iki şerefeli üzeri çatrilerle örtülü sekizgen mermerden yapılmış dört adet minaresi bulunmaktadır. Yapının 72 metre yüksekliğindeki minareleri, ana kubbesinden daha uzundur. Minarelerinin de sütunlarla taşınan çatrilerinin üzeri kubbelerle örtülmüştür. Türbeye güney cephede yer alan taçkapıdan girilmektedir. Diğer cephelerde yer alan taçkapıların mermerden ajur-delikişi şebekelerle kapalı olduğu görülmektedir. Taç kapının her iki yanında yer alan köşe mekânlarının bulunduğu alana ise girişi sağlayan dışardan giriş kapıları bulunmaktadır. Aynı zamanda içerden bu mekânlar ana mekâna açılmaktadır (Şekil: 1, Kesit: 1, Plan: 1-2).

Türbenin genel olarak bakıldığında diğer Babürlü türbe örneklerinden daha belirgin olan dikeyliği dikkat çekmektedir. Burada dikeyliği sağlamak amacıyla kemerlerin daha yüksek tutulduğu köşe mekânlarının ise daha dar bir şekilde ve yine dikeyselliği güçlendirmek amacıyla iki katlı eyvan şeklinde daha yüksek kemerlerin kullanıldığı görülmektedir. Asher'e göre bu dikeysellik, oldukça yenilikçi görünmesini sağlayan yeni bir mekânsal düzenlemenin ortaya konulmasıdır. Mekânsal düzenlemedeki bu hızlı değişim, onsekizinci ve ondokuzuncu yüzyıl mimarisi için yenilikçi yönleri tetiklemektedir (Asher, 1992: 21-69). Bibi Ka Makbere plan itibariyle daha önce yapılmış benzer plan özelliklerine sahip Delhi'deki Hümayun Türbesi ve Abdürrahim Han Türbesi ile Agra'da bulunan Tac Mahal Türbesi'nin aksine bütün mekânsal oranların dengesinin uyumlu oluşu ile değil ana mekânı çevreleyen ve bütün cephede ve iç mekânda hissedilen dikeyselliğin vurgulanışının somut bir kanıtıdır. Ancak bu mimari yenilikten ziyade Babürlü geleneğinin yanı sıra eserin bulunduğu bölgede yer alan Dekkani örneklerinden ve diğer (Bijapur, Golkonda gibi...) mimari eserlerden etkilenerek bu kayıtsız kalınamayacak etkileşiminin de bir sonucu olarak görülmektedir. 


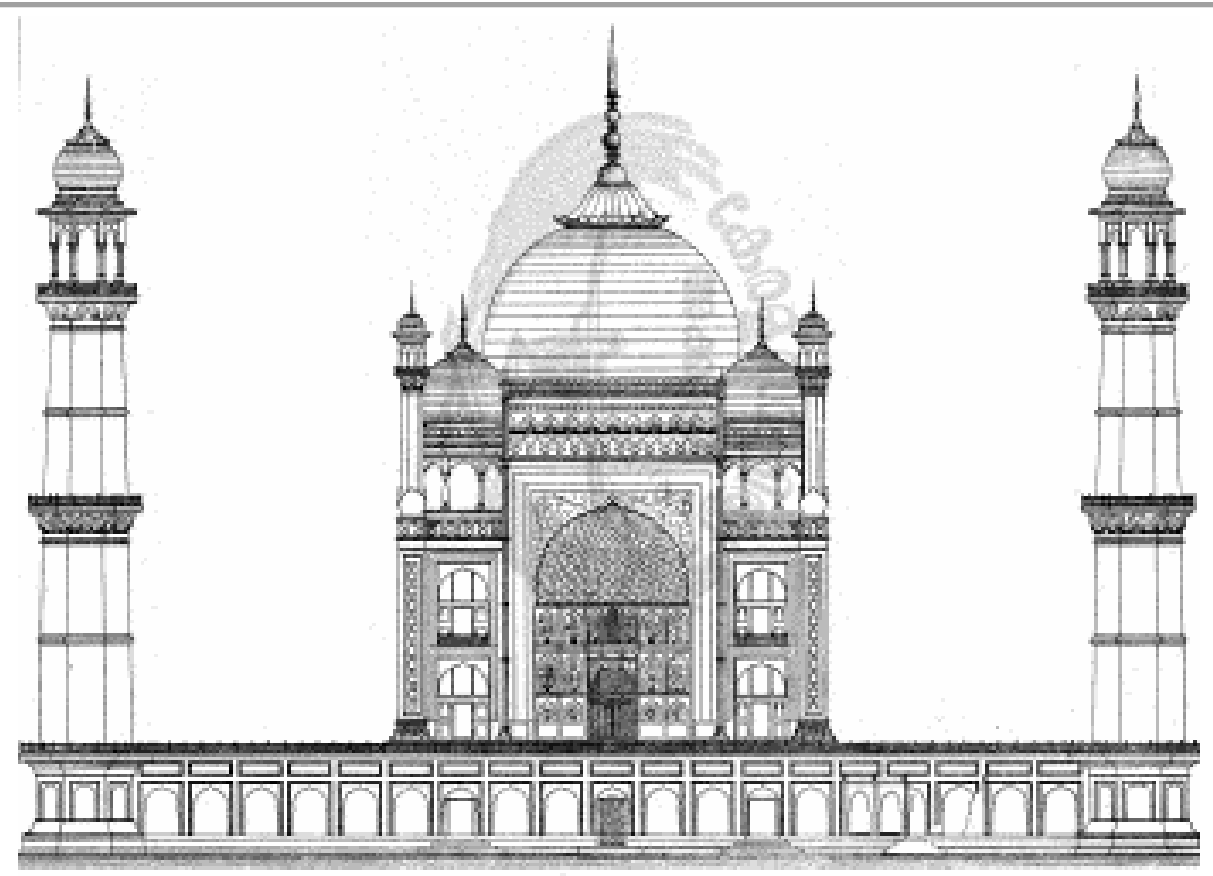

Şekil:1 Bibi Ka Makbere (The Nizam’s Government Archaeological Department,1918)
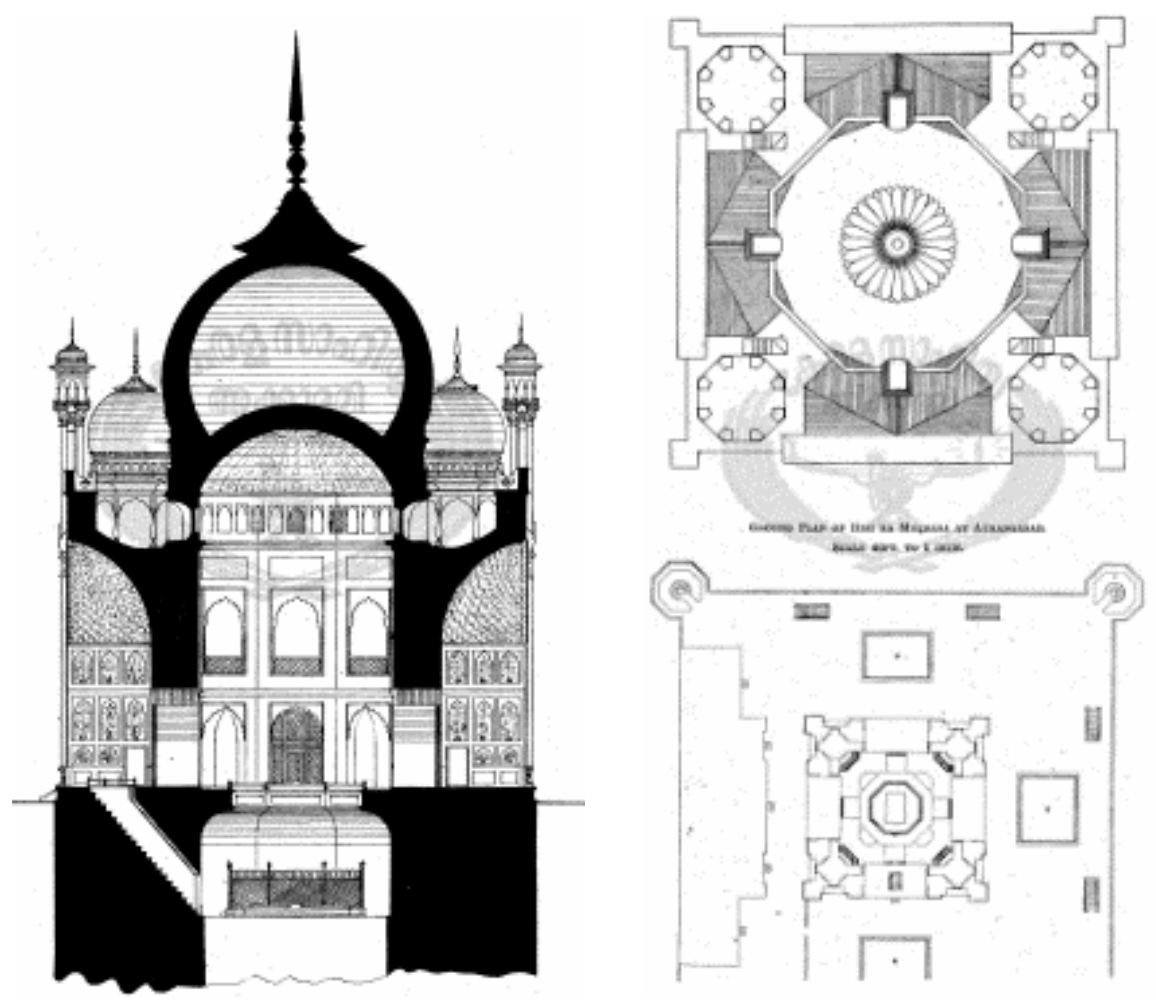

Kesit:1, Plan:1-2 Bibi Ka Makbere (The Nizam's Government Archaeological Department,1918) 
Yoğun cephe süslemelerine sahip olan türbenin güney cepheden tek girişi mevcuttur. Diğer cephelerin eyvan düzenlemeleri delikişi (jali) şebekelerle kapatılmıştır. İç mekânda zeminden aşağ1 doğru bakıldığında üzeri açık bırakılmış sekizgen bir alan içerisinde mermerden yapılmış ana mezar sandukası görülmektedir. Türbeyi diğer Babürlü türbelerinden farklı kılan özelliği ise köşe mekânlarında ve üst katında hanedan üyelerine ait mezar sandukalarının olmadığı gibi üst katında sembolik mezar sandukasının da bulunmaması ve Rabia-ud Devrani'ye ait olan tek bir mezar sandukasının ise sadece alt katta yer almasıdır. Türbenin ana mekânının tam ortasında açık bir vaziyette alt katında sekizgen muhaccer çerçeve ile kuşatılmış, beyaz mermerden yapılmış olan mezar sandukasının üzeri yeşil örtü ile kapatılmıştır (Foto: 11-12).
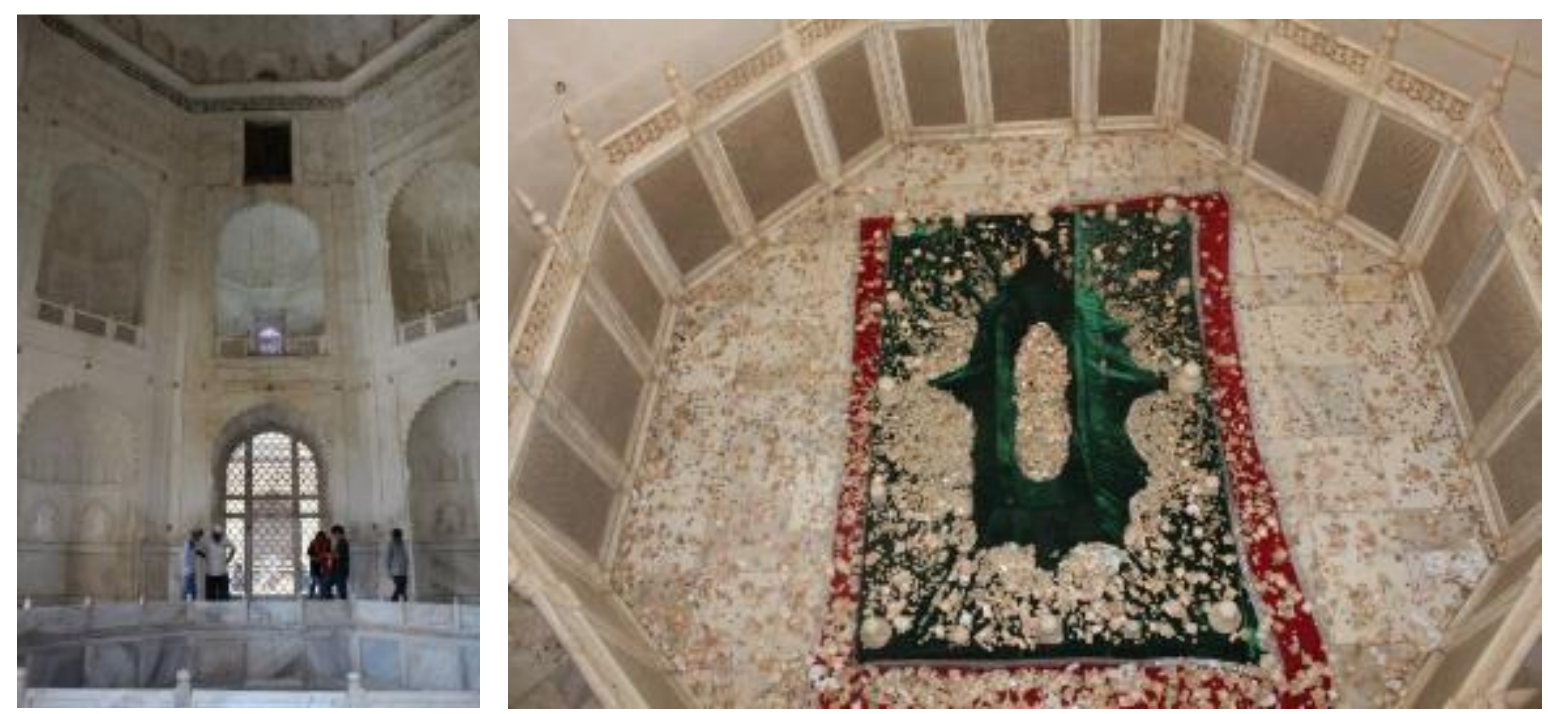

Fotoğraf: 11-12 Bibi Ka Makbere İç Mekânı, Mezar Sandukası ve Çevresi Genel Görünüşü

(Özler,2017)

Bibi Ka Makbere mimarisi kadar üzerinde yer alan süslemeleri ile de önemli bir yapıdır. Bitkisel motifler, geometrik desenler, yazı ve nesneden oluşan süslemeler yer almaktadır. Türbenin süslemelerini ağırlıklı olarak bitkisel süslemeler oluşturmaktadır. Türbede aslına yakın tasvir edilen natüralist çiçekler yanında yarı stilize olmuş ve tam stilize olmuş çiçek motifleri de kullanılmıştır. Dış cephe ve iç mekân duvar yüzeylerinde her bir niş içerisine alınmış vazodan çıkan bitkisel süslemeler; geç dönem Babürlü stilini yansıtan natüralist bitkisel motiflerden oluşmaktadır. Türbede; zambak, nergis, gül, gelincik yanında palmet, rumi ve lotus motifleri kıvrık dallarla birlikte kullanılan bitkisel motifler arasındadır. Dilimli kemerler; yapının genelinde yoğun bir şekilde kullanılmıştır.

Yapının süslemeleri; dış cephede ilk olarak platformun yüzeyinde kalp biçiminde bir çerçeve içerisinde ters şekilde işlenmiş palmet motifi ile karşımıza çıkmaktadır. Platformun her bir kenarında 19 adet kemer gözü bulunmaktadır. Platformun Kuzey-Güney ve Doğu kenarlarında üst kata 2 adet dilimli kemerli giriş açıklığı bulunmaktadır. Bu giriş açıklığında ve sağır niş şeklinde yapılmış kemerli bölümler dilimli şekilde platformun yüzeyini hareketlendirmiştir. Platformun korkuluklarında ise kırmızı kumtaşından yapılmış korkuluk şebekelerinde çokgen formlarda ağırlıklı olarak sekiz kollu yıldızların oluşturduğu geometrik şekiller mevcuttur. Platformun zemin yüzeyinde herhangi bir bezeme bulunmayıp blok mermer taşlarla döşenmiştir. Platformun Kuzey-Güney ve Doğu cephelerinin kenar ortalarında bulunan dikdörtgen havuzlarında da herhangi bir süsleme unsuruna rastlanmamıştır. Yapının platformunun dört köşesinde yer alan minarelerinin üzerindeki süslemelerin çoğu günümüze ulaşamamış yalnızca şerefelerinde kenger yaprakları bulunmakta ve çatri yüzeyinde ters-düz palmet dizileri yer alırken çatrinin üzerinde yer alan soğanvari kubbe dilimli lotus kaide üzerinde oturan pirinç âlemle son bulmaktadır (Foto: 13-14). 

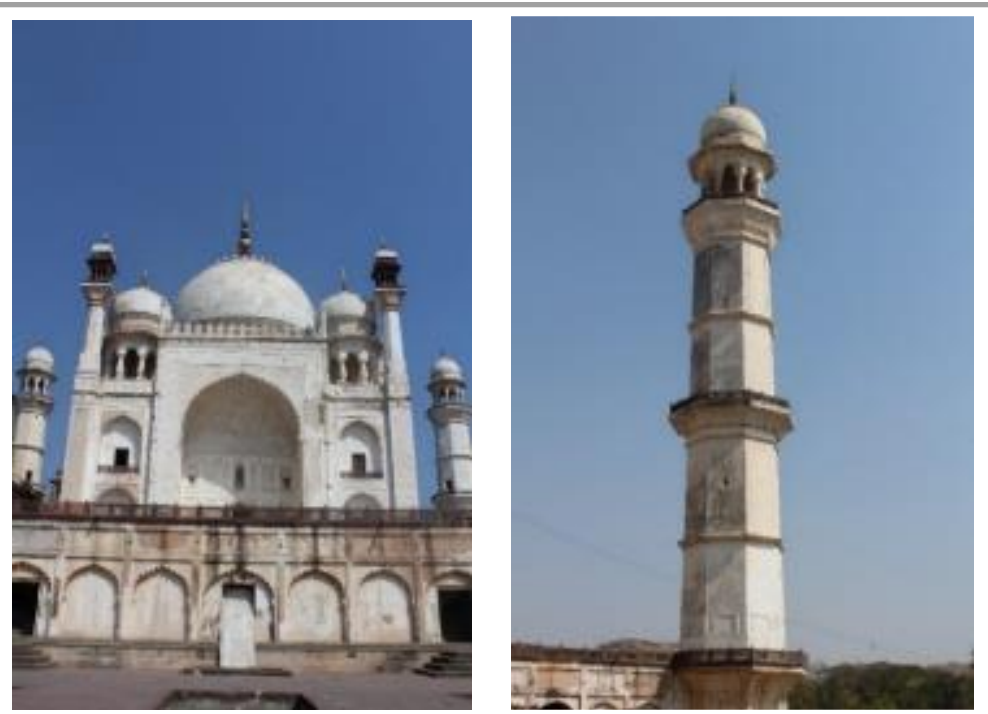

Fotoğraf: 13-14 Bibi Ka Makbere Genel Cephe Görünüşü (Özler,2017)

Yapının Kuzey-Güney-Doğu ve Batı cephelerinin simetrik olarak aynı süsleme kompozisyonlarına sahip olduğu detayda bitkisel motiflerinde farklılıkların olduğu görülmektedir. Yapının anıtsal eyvan düzenlemesine sahip anıtsal taç kapısı bulunmakta ve simetriği sağlamak için bütün cephelerde bu anıtsal eyvan düzenlemelerinin tekrarlandığını ancak güney cephe dışında diğer cephelerde ajurlu şebekelerle (jalilerle) kapalı olduğu görülmektedir (Foto: 15-16). Güney cephede ise ayrıca yüzeyi bitkisel süslemelerle hareketlendirilmiş metal ahşap kaplamalı kapısı vardır (Foto: 17-18).
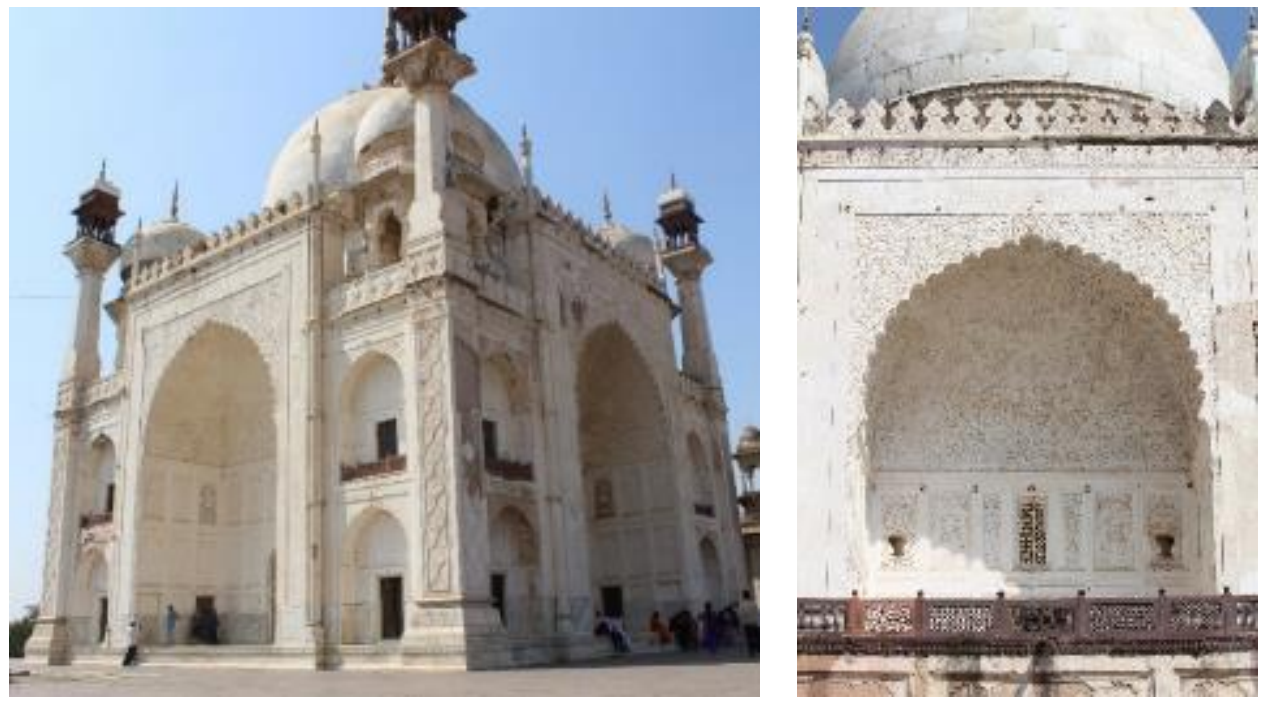

Fotoğraf: 15-16 Bibi Ka Makbere Dış Cephe Genel Görünüşü (Özler,2017) 

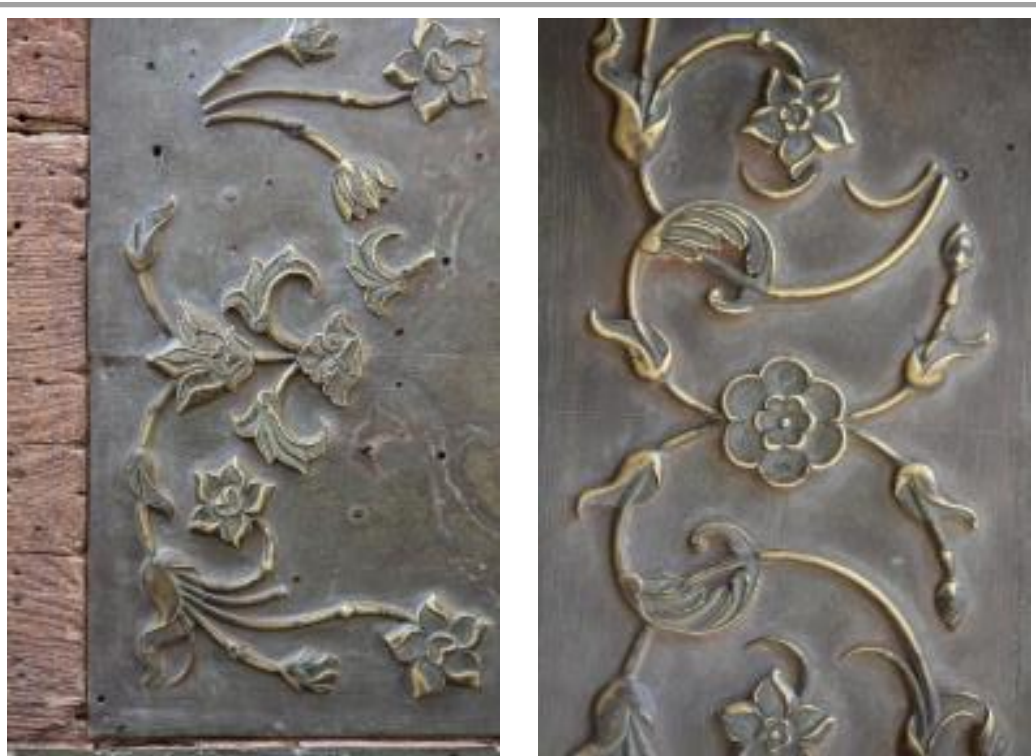

Fotoğraf: 17-18 Bibi Ka Makbere Giriş Kapısı Genel Görünüşü (Özler,2017)

Yapının duvar yüzeylerinde eyvanlarının yaklaşık 1 metre yüksekliğe kadar dikdörtgen panolarla kaplanmış olduğu görülmektedir. Bu panoların yüzeyleri sade bırakılmıştır. Hemen üzerinde yer alan bölüm ise kubbeye kadar sağır nişlerle hareketlendirilmiştir. Her bir nişin içerisinde farklı bitkisel motifler yer alırken bunlar; genel olarak zambak, nergis, gül motiflerinden oluşmaktadır. Bu motifler niş içerisinde vazodan veya topraktan çıkar şekilde oldukça natüralist biçimde duvar yüzeyine işlenmişlerdir. Tac Mahal'de zeminden 1 metre yüksekliğe kadar yer alan yatay dikdörtgen panolar (dadolar) yoğun bitkisel motiflerle süslü olup, üst kısımları eyvan ve kemerlerin yüzeyleri boş bırakılan sağır nişlerle hareketlendirilirken burada tam aksine dadolar sade üst kısımlar sağır nişler yoğun bitkisel motiflerle işlenmiştir. Nişlerin üzerinden kemer kavsarası ve kemer alınlığına kadar yoğun bitkisel motiflerin kıvrık dallarla çerçeve içine alınmış bitkisel motiflerin bütün yüzeyi boş bırakılmadan kapladığı görülmektedir (Foto: 19-23).

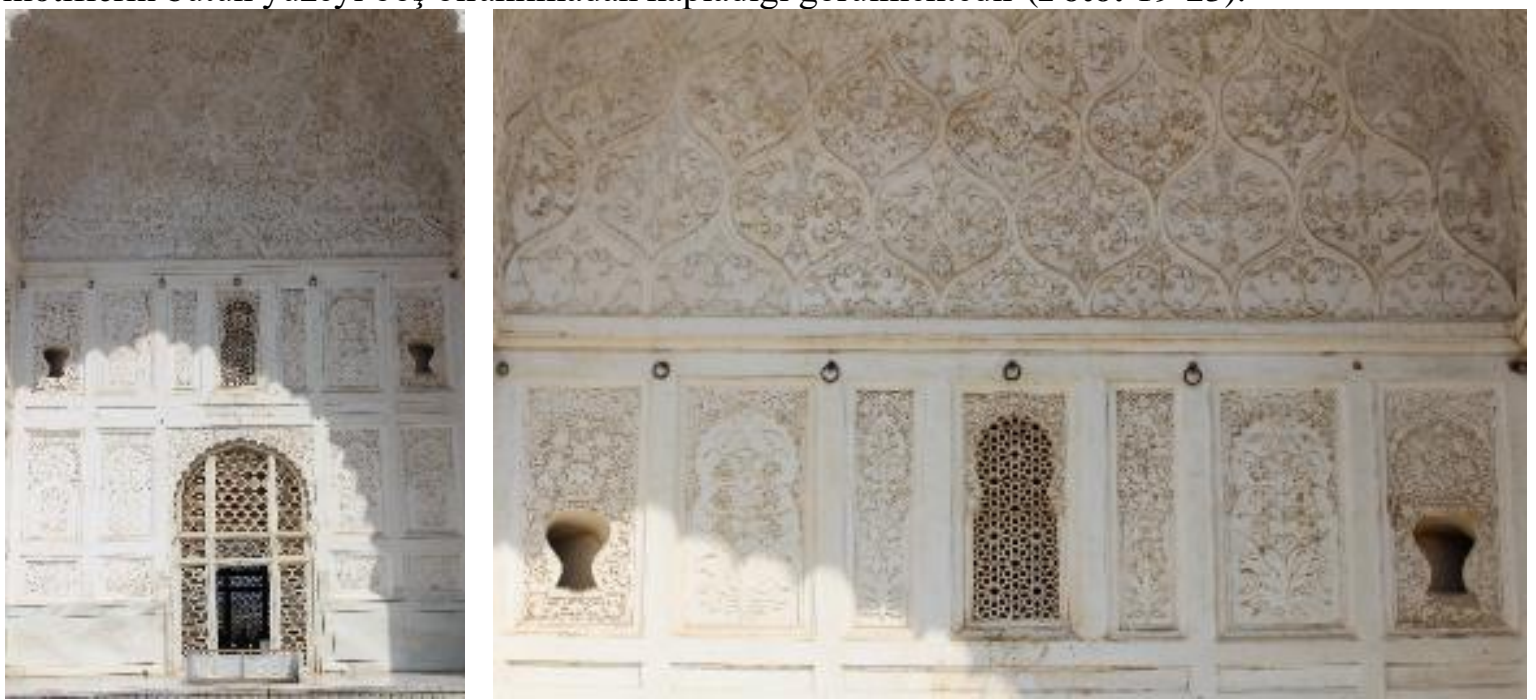

Fotoğraf: 19-20 Bibi Ka Makbere Dış Cephe Süslemeleri Genel Görünüşleri (Özler,2017) 

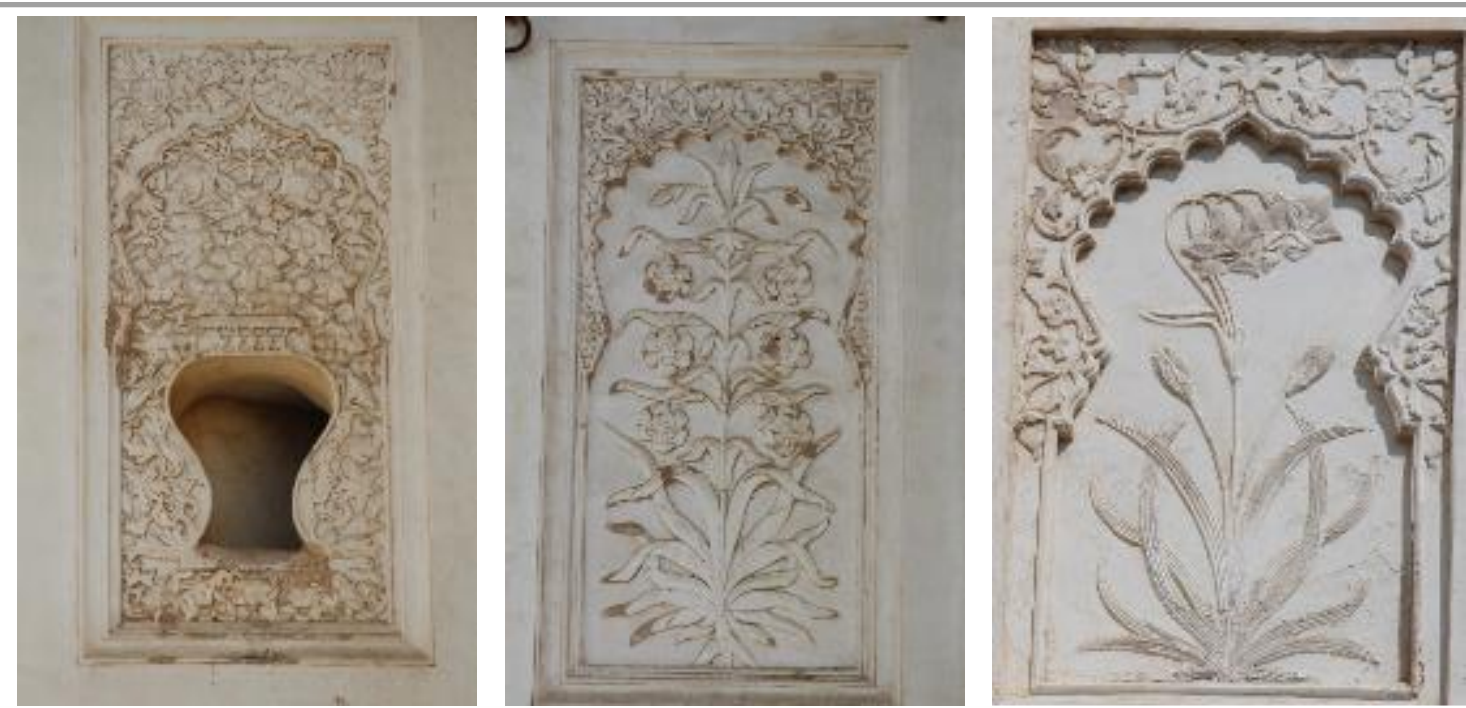

Fotoğraf: 21-22-23 Bibi Ka Makbere Dış Cephe Süslemeleri Genel Görünüşleri (Özler,2017)

Taç kapının tepeliği ise alt kısmı yukarı doğru daralan üç dilimli palmet motifi ile sonlanan sıralı palmet dizisi ile sonlandırılmış bu tepeliğin yüzeyinde kökleri ve yaprakları ile tasvir edilmiş lotus motifi işlenmiştir. Taç kapının tepeliğinin her iki ucunda simetrik olarak bütün cephede bulunan, Babürlü mimarisinde yaygın bir şekilde kullanılan çokgen formlu sütünce üzerinde dilimli lotus ile sonlandırılmış bölgede güldeste diye adlandırılan yapı öğesi- köşe sütunceleri yer almaktadır. Yapının mukarnas dilimli kaideye oturan beyaz mermerden kubbesi Hümayun Türbesi ve Ategeh Han Türbesinin kubbe kaidesi ile benzerlik göstermektedir. Kubbe dilimli lotus kaide üzerinde pirinçten yüzeyinde herhangi bir bezemesi bulunmayan sade bir âlemle sonlandırılmıştır. Türbenin yan mekânlarının üzerinde yer alan çatrilerin yüzeyinde de aynı minarelerinde olduğu gibi ters-düz palmet dizileri yer alırken çatrinin üzerinde yer alan soğanvari kubbe dilimli lotus kaide üzerinde oturan pirinç âlemle son bulmaktadır. Yapının üzerinde yer alan bitkisel süslemeler yüksek kabartma ve oyma tekniği ile yapı yüzeyine uygulanmıştır (Foto: 24-27).
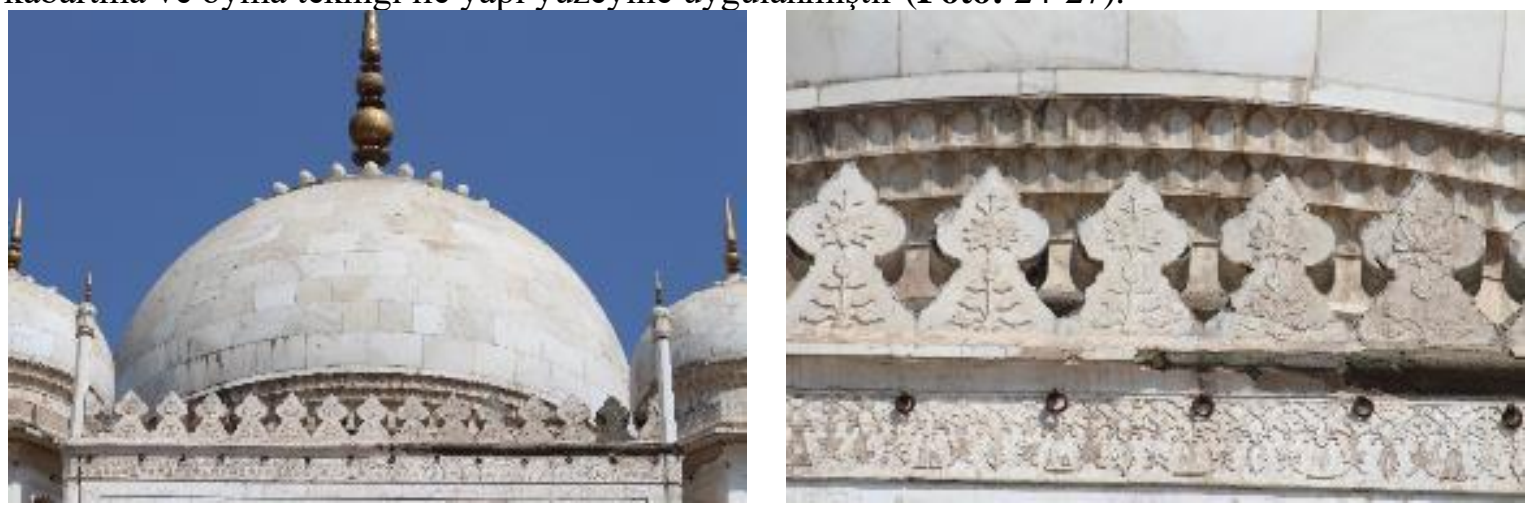

Fotoğraf: 24-25 Bibi Ka Makbere Dış Cephe Süsleme Detay Görünüşleri (Özler,2017) 

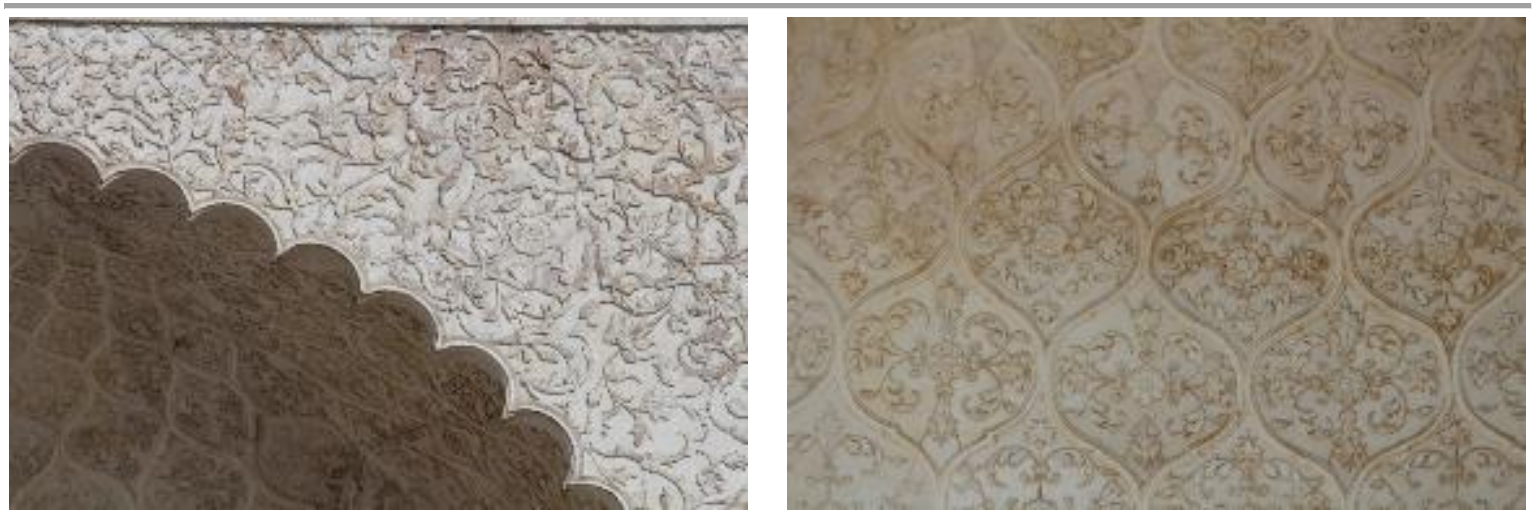

Fotoğraf: 26-27 Bibi Ka Makbere Dış Cephe Süsleme Detay Görünüşleri (Özler,2017)

Yapının köşe mekân hücreleri ise iki katlı olarak düzenlenmiştir. Yapının ana eyvanı ile süsleme programı bütünlük sağlamakta burada hem ön cepheden hem de yan kanatlardan giriş açıklığ 1 bulunmaktadır. Buradaki açıklıklar ahşap kapı kanatlarıyla kapatılmıştır. Bu bölümde de yap1 genelinde görülen yatay panolar kare şeklinde olup, yüzeyi boş bırakılmıştır. Hemen üzerinde kapıyı çevreleyen dilimli kemerin iç kısmında niş içerisinde bitkisel motifler bulunmakta ve burada zambaklar, nergisler yanında gül motifleri de yer almaktadır. Yapının dilimli kemerinin alınlık yüzeyi ise kıvrık dallar arasında palmet, lotus, zambak, nergis ve hatailerle süslenmiştir. Bu bölümün kenar köşelerinin dikey dikdörtgen şekilde dışa çıkıntı yapacak şekilde vurgulandığı görülmektedir. Bu payanda gibi dışa çıkıntı yapan duvarın kaidesini iri biçimde kenger yaprakları ile süslenmiş ve içlerinde lotus motifi işlenmiştir. Siyah beyaz mermerle zikzak şeklinde kaide ile ayrılan bu bölümün üzeri tepeliğe kadar kıvrık dallarla volüm yaparak geçme şeklinde devam ettirilmiştir. Bu volümlü çerçevelerin yüzeyleri yoğun bitkisel motiflerle doldurulmuştur (Foto: 28-32).
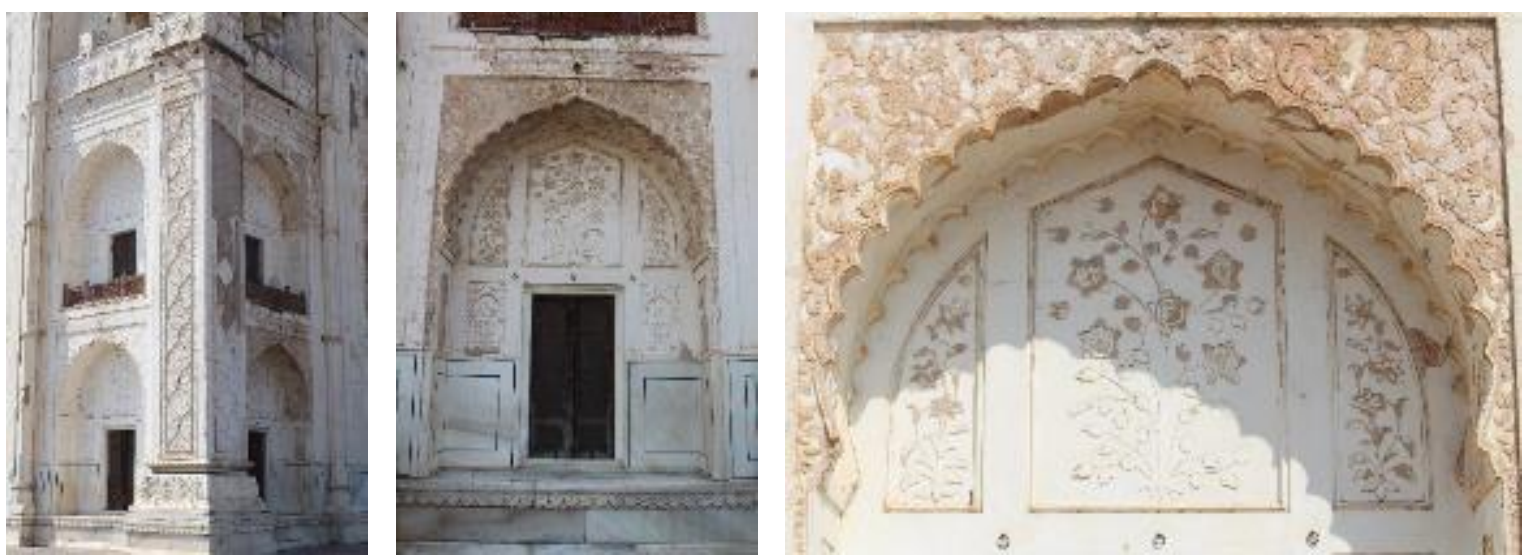

Fotoğraf: 28-29-30 Bibi Ka Makbere Dış Cephe Köşe Mekân Süslemeleri Genel Görünüşleri (Özler,2017) 

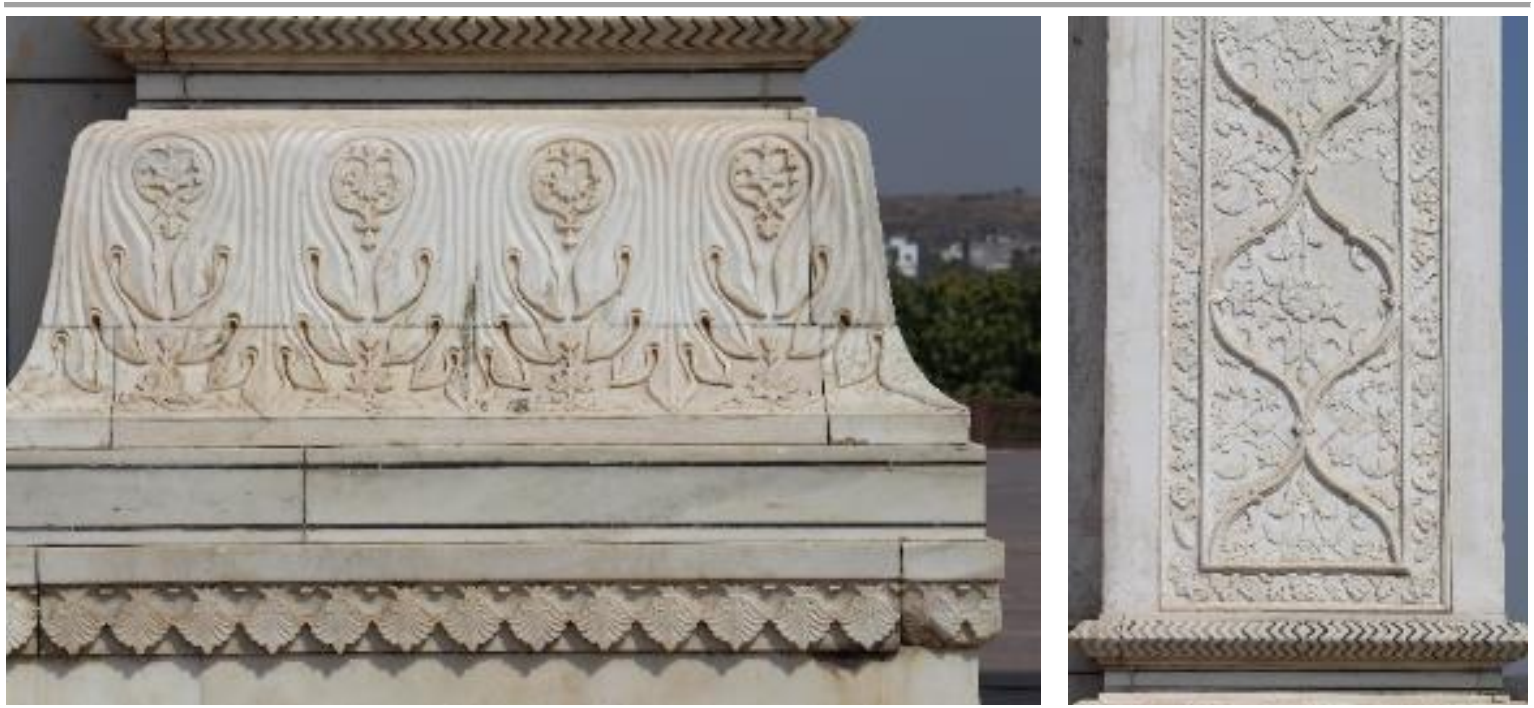

Fotoğraf: 31-32 Bibi Ka Makbere Dış Cephe Köşe Mekân Süslemeleri Genel Görünüşleri (Özler,2017)

Yapının iç mekân süslemelerine bakıldığında ise yapının giriş kapısından itibaren dilimli kemerler ve yoğun bitkisel süslemeler görülmektedir. Yapının iç mekânında zeminin beyaz mermerden döşeli olduğu üzerinde herhangi bir bezemenin olmadığg görülmektedir. Zeminden 1 metre yüksekliğe kadar yer alan yatay dikdörtgen panoların yüzeyleri dış mekânda olduğu gibi burada da boş bırakılmıştır. Hemen üzerinde yer alan dilimli şekildeki sağır nişlerin içerisinde kökleri ve yaprakları ile birlikte zambak, ters lale, gül motiflerinin yüksek kabartma ve oyma tekniği ile duvar yüzeyine işlendikleri görülmektedir (Foto: 33-35).
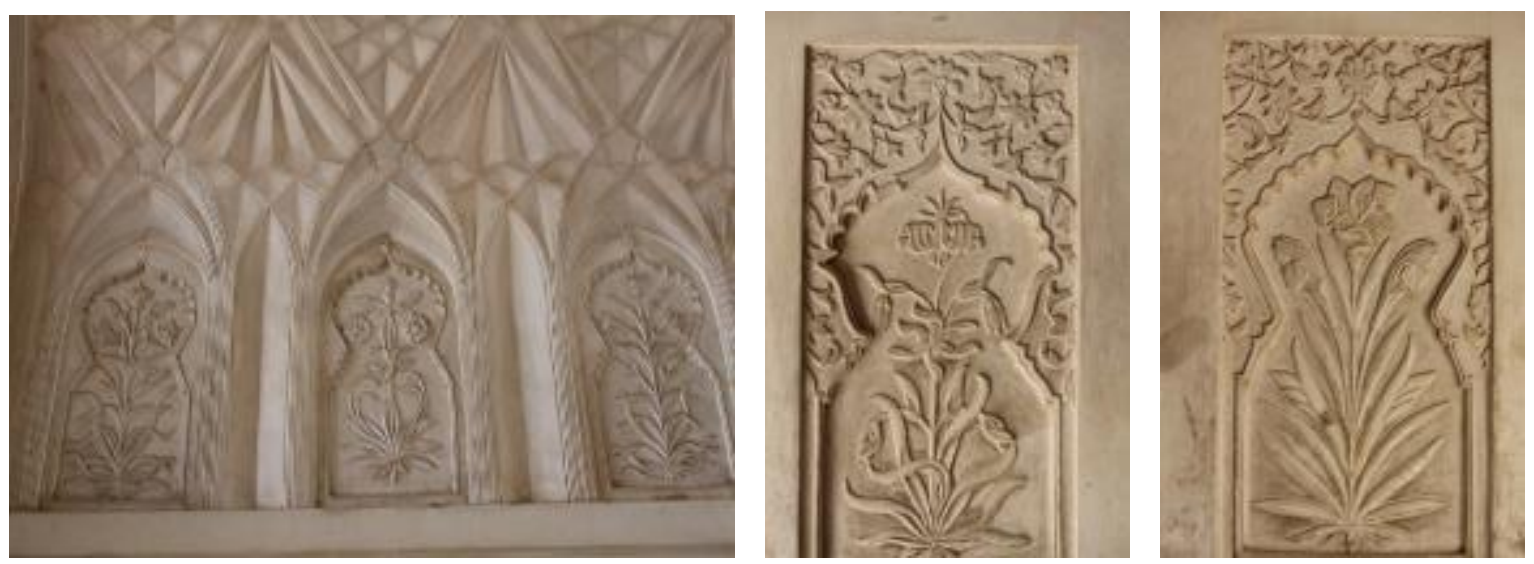

Fotoğraf: 33-34-35 Bibi Ka Makbere İç Mekân Detay Süslemeleri (Özler,2017)

Genel olarak iç mekânda da bitkisel bezemeler niş içerisinde yer almakta ve duvar yüzeyleri alçı ve kireç taşı karışımından oluşmaktadır. Yapının sekizgen iç mekanının iki katlı eyvan düzenlemeleri dilimli kemerlerle hareketlendirilmiştir. Üst katta yer alan eyvanların yüzeyleri sağır nişlerle hareketlendirilirken; mukarnasvari, yıldız ve baklava dilimi şeklinde geometrik desenlerle yüzeyi hareketlendirilmiş tonozla örtülmüştür (Foto: 36-37). 

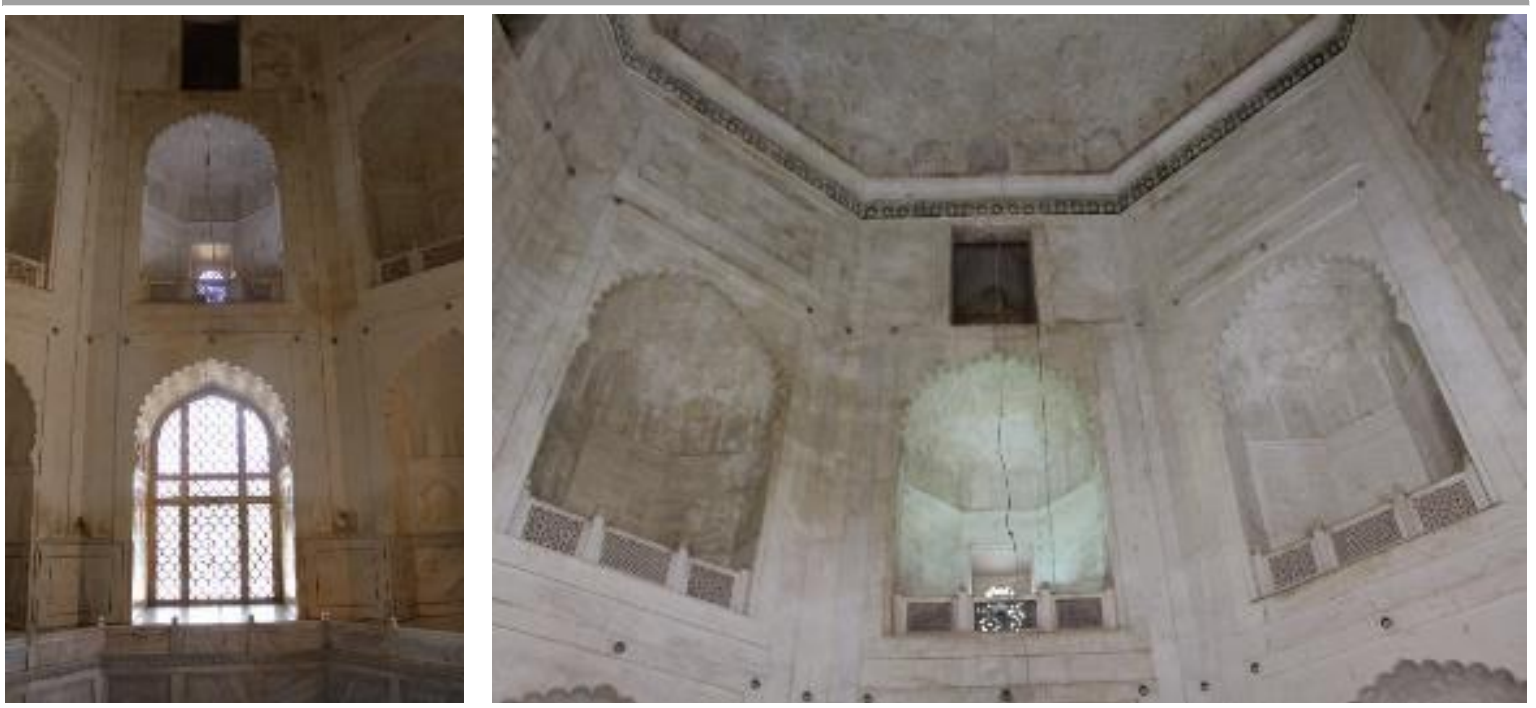

Fotoğraf: 36-37 Bibi Ka Makbere İç Mekân Genel Görünüşü (Özler,2017)

Türbenin sekizgen kasnağ iki yatay şeritle çerçevelenmiş bu yatay şerit yüzeyi palmet, rumi, lotus yanında stilize çiçeklerle süslenmiştir. Yapının kubbe kasnağında otuz iki adet niş bulunurken bunların ikisi sivri kemerli ve açık (pencere niteliğinde), diğerleri dilimli kemerli olup kapalı ve yüzeylerinde herhangi bir bezeme unsuru bulunmamaktadır. Kubbenin karnı yüzeysel şekilde mukarnasvari bir süslemeye sahip olup kubbe göbeğinde sekiz yapraklı lotus çiçeği yer almaktadır. Lotus motifi yeșil, turuncu renkte beyaz alçı üzerine ișlenmiștir (Foto: 38-39).
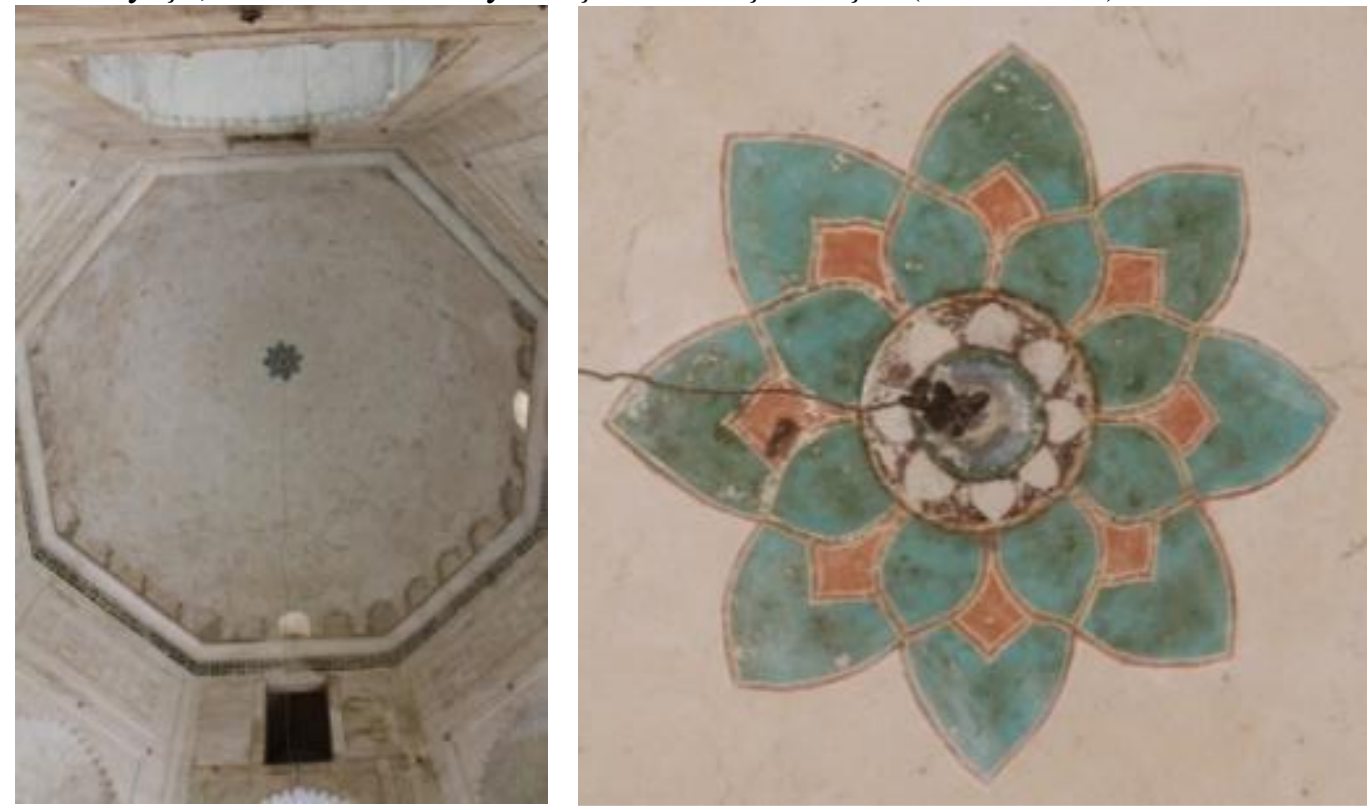

Fotoğraf: 38-39 Bibi Ka Makbere Kubbe Genel ve Detay Görünüşleri (Özler,2017) 


\section{Değerlendirme}

Babürlü devletinin önemli altı hükümdarı; Babür Şah (1483-1530), Hümayun Şah (15051556), Ekber Şah (1542-1605), Cihangir Şah (1569-1627), Şah Cihan (1592-1666) ve son olarak Evrengzib Şah (1618-1707) yılları arasında yaşamışlardır. Babürlüler döneminde özellikle Ekber Şah ile sistemli bir şekilde başlayan imar faaliyetleri Cihangir ve Şah Cihan dönemlerinde daha da yoğunlaşarak ilerlemiştir. Evrengzib döneminde de birçok mimari eser ortaya konulmuş ancak Cihangir ve Şah Cihan dönemlerine nazaran mimari faaliyetlerde ciddi bir duraklama yaşanmıştır. Babürlü mimarisinde birçok yapı tipinde eserler inşa edilmiş; ancak yapı grupları içerisinde, türbeler önemli bir yer tutmaktadır. Anıtsal ölçekte ve birbiri ardına çok sayıda türbe inşa edilmiş, ancak hükümdarlarının hiçbiri aynı șehirde gömülmemiștir. Babür Şah'ın Türbesi Kabil'de, Hümayun'un Türbesi Delhi'de, Ekber Şah'ın Türbesi Sikandara'da, Cihangir'in Türbesi Lahor'da, Şah Cihan'ın Türbesi Agra'da ve Evrengzib'in Türbesi Evrengabad'ta bulunmaktadır. Babürlü hükümdarlarının her biri; malzeme, teknik, mimari ve tasarım olarak birbirinden farklı özellikleri olan anıtsal türbelere sahiptir (Özler, 2018: 220). Babürlüler döneminde devletin ileri gelen kadınları için de önemli türbeler inşa edilmiştir. Ekber Şah'ın eşi Cihangir'in annesi Meryem-uz Zamani için yaptırmış olduğu Sikandara'daki türbesi, Cihangir'in ilk eşi Şah Begüm'ün Allahabad'daki türbesi ve yine Cihangir'in eşi Nur Cihan Hatun'un Lahor'da kendi baniliğinde yaptırmış olduğu türbesi, Şah Cihan'ın eşi Mümtaz Mahal için yaptırmış olduğu Tac Mahal ve Evrengzib'in eşi Dilras Banu Begüm için yaptırılan Bibi Ka Makbere inşa edilen kadın sultanlara ait önemli örneklerdir. Bu önemli türbelerden biri olan Şah Cihan'ın eşi Mümtaz Mahal için (1631-48) yaptırmış olduğu Agra şehrindeki Tac Mahal Türbesi belki de türbe mimarisini yalnız Babürlü dönemi içinde değil, Türkİslam dönemi kapsamında da erişilmez kılmış ve türbe mimarisini son safhasına ulaştırmıştır. Tac Mahal, kendinden sonra yapılan birçok türbeye örnek teşkil etmiş olabileceği gibi öncesinde ve sonrasında inşa edilen birçok anıtsal mezarı gerisinde bırakmıştır. Araştırma konusunu oluşturan Bibi Ka Makbere için de Tac Mahal Türbesi adeta bir prototip oluşturmaktadır. Türbe; hükümdar Evrengzeb'in validesi olan Mümtaz Mahal'in türbesi Tac Mahal ile genel olarak benzetilmekte ve bundan dolayı "Dekkan'ın Tacı ya da Mini Tac Mahal" şeklinde adlandırılmaktadır. Ancak Tac Mahal ile benzerliği mimari olarak neredeyse hiç yoktur. Babürlü döneminin son anıtsal türbesi olan Bibi Ka Makbere plan ve mimari özellikleri ile daima Tac Mahal ile mukayese edilmiş hatta birçok araştırmacı tarafından "Tac Mahal' in kopyası" şeklinde ifade edilmiştir.

İlk bakışta Tac Mahal'i anımsatan ancak detaylı bir şekilde incelendiğinde her iki yapının aslında plan, mimari, malzeme ve tasarım olarak birbirinden çok farklı özelliklere sahip oldukları görülmüştür. $\mathrm{Bu}$ önemli iki anıtsal eseri kıyaslamadan önce her iki türbenin de yapım dönemlerinde devletin siyasi ve ekonomik olarak bulunduğu ortamın göz önünde bulundurulması gerekmektedir. Çünkü Tac Mahal yapıldığı dönemde Babürlüler'in en ihtişamlı oldukları saltanat yılları yaşanırken; Bibi Ka Makbere'nin inşa edildiği sıralarda devletin iç ve dış savaşlarla mücadele ettiği zor günlerine denk gelmiştir. $\mathrm{Bu}$ durumun her iki yapının plan ve mimari özelliklerinden tasarımına, inşa malzemesinden boyutuna hatta yapım sürelerine kadar birçok konuda olumlu ve olumsuz yönde etkilerinin olması kaçınılmaz olmuştur. Hem Tac Mahal hem de Bibi Ka Makbere bulundukları şehre hâkim yerlerde inşa edilmiş şehrin siluetini de etkileyen Babürlü dönemi mimarisi için önemli türbe örneklerindendir. Bibi ka Makbere de tıpkı Tac Mahal gibi, bulundukları şehirde tipik Babürlü mimarisinin bir sembolü haline gelmiştir.

Plan ve mimari özelliklerine bakıldığında; her iki örnek arasında ciddi farklar görülmektedir. Çar bağ düzenine sahip bahçe tasarımı, Bibi Ka Makbere'nin Tac Mahal ile ortak gibi görünen bir özelliğidir. Ancak Tac Mahal'de ana yapıya doğrudan erişimi engelleyen ana bahçenin ön kısmında anıtsal dört giriş bina düzenlemesinin olduğu ön bahçe kısmı bulunmaktadır. Bibi Ka Makbere'de ise ana bahçeden türbeye geçiş doğrudan sağlanmaktadır. Ayrıca Tac Mahal bahçenin sonunda, nehrin kıyısında, kırmızı kumtaşından yapılmış simetriğinde yer alan camisi ve mihmanhanesinin tam merkezinde yer alırken, Bibi Ka Makbere bahçenin tam merkezinde ve aynı platform üzerinde 
hemen batısında yer alan aynı malzemeden yapılmış camisi ile birlikte yer almaktadır. Her iki yapıda platform üzerinde inşa edilmiştir. Tac Mahal'in planı dışarıdan kare içeriden sekizgen bir plana sahip iken Bibi Ka Makbere dışarıdan kare içeriden sekizgen bir plana sahiptir. Tac Mahal'in plan ve anıtsal ölçüleri de Bibi Ka Makbere ile oldukça farklılıklara sahip olup özellikle Bibi Ka Makbere'nın gövdesinin dikeyliği dikkat çekecek boyuttadır. Yapının mekânsal arayış nedeniyle orantısız olduğu özellikle Asher tarafindan vurgulanmakta ancak oda bu durumu dikeyliğine dayandırmaktadır. Türbeyi diğer Babürlü türbelerinden farklı kılan özelliği ise köşe mekânlarında ve üst katında hanedan üyelerine ait mezar sandukalarının olmadığı gibi üst katında sembolik mezar sandukasının da bulunmaması ve Rabia-ud Devrani'ye ait olan tek bir mezar sandukasının ise sadece alt katta yer almasıdır. Türbenin ana mekânının tam ortasında açık bir vaziyette alt katında sekizgen muhaccer çerçeve ile kuşatılmış, beyaz mermerden yapılmış olan mezar sandukasının üzeri yeşil örtü ile kapatılmıştır. Tac Mahal'in sandukaları hem alt katta hem üst katta beyaz mermerden üzeri renkli taşlarla çeşitli bitkisel bezemelerle süslenmişken Bibi Ka Makbere'nin alt katta yer alan beyaz mermer sandukası sade bırakılmıştır. Tac Mahal'in asıl mezar sandukalarının yer aldığı alt katına giriş yasak iken, Bibi Ka Makbere'nin tek mezar sandukasının yer aldığı alt katına ziyaretçilerin girişine izin verilmemekte ancak zemin kattan üzeri açık bırakıldığ 1 için mermerden sekizgen bir muhaccer çerçeve ile tasarlanmış bölümü görülebilmektedir. Her iki türbede de mezar sandukaları muhaccer çerçeve ile kuşatılmıştır. Ancak Tac Mahal'in üst katında sembolik sandukaların yer aldığı bölümü kuşatan bu çerçeveler beyaz mermerden olup, üzerinde renkli taş süslemelerle oluşturulan yoğun bitkisel süslemeler yer alırken, Bibi Ka Makbere'de asıl mezar sandukasını kuşatan muhaccer çerçevenin yine mermer malzemeden yapıldığı ancak geometrik delik işi ile oluşturulan süslemelerin dışında oldukça sade bırakılmış olduğu görülmektedir.

Her iki yapının ana mekanının üzeri soğan kubbelerle örtülmüştür. Tac Mahal'in kubbesi yapının üzerinde bütün yapıya ve köşe mekânlarının üzerinde yer alan çatrilerin yanında, onlara hâkim bir genişlik ve yükseklikte iken, Bibi Ka Makbere'nin kubbesi daha dik olup yan hücrelerinin üzerinde yer alan çatrilerin kubbeleri ile birlikte yakın ölçülere sahip olmasından dolayı kubbenin yapının bütününe hâkim olmadığı izlenimi oluşmuştur. Tac Mahal'in kubbesi minarelerinde yüksek iken, Bibi Ka Makbere'nin minareleri ana kubbesinden daha yüksek tutulmuştur. Her iki yapının minareleri de yapının platformunun köşelerine yerleştirilmiş yapının bünyesinden ayrı olarak inşa edilmiştir. Tac Mahal'i minareleri; yuvarlak formlu yukarı doğru daralırken üç şerefeli olarak yapılmış, Bibi Ka Makbere'ninki ise sekizgen formlu ve iki şerefeli olarak inşa edilmiştir. Tac Mahal'in minareleri çatrilerle sonlandırılırken, Bibi Ka Makbere'nin minareleri kubbe ile nihayetlendirilmiştir. $\mathrm{Bu}$ da bölgesel olarak Dekkani etkisini göstermekte çünkü Dekkan örneklerinde de Bibi Ka Makbere'de olduğu gibi sekizgen minareler bulunmakta ve üzerleri çatri yerine kubbelerle örtülmektedir.

Bibi Ka Makbere'nin dört yönünde eyvan düzenlemesi ve piştak uygulamaları ile geleneğe bağlı olduğunu göstermektedir. Özellikle eyvan ve piştak düzenlemeleri Tac Mahal'inki ile benzerlik göstermektedir. Yapının üst örtüsünde yer alan kubbe ile yakın ölçülere sahip çatri uygulamaları Babürlü mimarisine Hint yerel kültürünün etkisiyle girmiştir. Bibi Ka Makbere türbesinin piştakları Timurlu geleneğinin bir devamı olarak nitelendirilirken ana kubbenin yanında ana mekânın etrafını çevreleyen köşe mekanların üzerini örten kubbenin dışarıdan çartilerle örtülmüş olması burada yerli kültürün bir sonucu olarak görülmektedir. Çatriler ise bölgede daha önce hiçbir yapıda görülmemektedir. Babürlü dönemi mimarisinin vazgeçilmez unsurlarından biri olan çatriler ilk olarak Hümayun Türbesi'nde karşımıza çıkmaktadır. Daha sonra inşa edilen birçok yapıda da yaygın olarak kullanılmıştır. Evrengabad bölgesinde ise daha çok Dekkani mimari eserleri inşa edilmiş olup çatri uygulamaları yerine güldestelerin kullanımının daha çok tercih edildiği görülmektedir. Ancak yapıda görülen dilimli kemerler Evrengabad bölgesinde Dekkani, Bijapur mimarilerinin etkilerinin bir sonucu olabileceği gibi daha önceki Babürlü örneklerinde de çok yaygın olmasa da kullanıldığ görülmektedir. Bibi Ka Makbere'den önce inşa edilen Babürlü dönemi eserlerinden; Agra ve Delhi 
Kalesi'nde ayrıca Tac Mahal'de camisi ve mihmanhanesinin kemerlerinde dilimli kemerler kullanılmıştır.

Her iki yapının mimari olarak benzer ve farklı özellikleri olduğu kadar süsleme, malzeme ve teknik açıdan değerlendirildiğinde de ciddi boyutta benzer ve farklılıklarının olduğu görülmektedir. Babürlü dönemi mimari eserlerine bakıldığında malzeme olarak kırmızı kumtaşı kullanımının erken y1llarda yaygın olduğunu Cihangir döneminde başlayan mermer kullanımının ise Şah Cihan döneminin ana malzemesi haline geldiği görülmektedir. Evrengzip zamanında ise bölgesel olarak yap1 malzemesinin değerlendirilmesi gerekmektedir. Çünkü Agra ve Delhi'deki yapılar beyaz mermerden iken Lahor'daki yapılar kırmızı kumtaşı ve beyaz mermer birleşiminden oluşmaktadır. Evrengabad'daki Bibi Ka Makbere örneğinde ise beyaz alçı ve kireç karıșımdan oluşan farklı bir malzeme arayışına gidildiği görülmektedir. Yapının malzemesi de Tac Mahal'inki ile mukayese edildiğinde Tac Mahal tamamıyla beyaz mermerden yapılmışken, Bibi Ka Makbere yer yer beyaz mermer (dış duvar yüzeyleri dadolara kadar, iç mekânda zemin ve duvarın 1 metre yüksekliğe kadar olan kısmı), kırmızı kumtaşı ve kireç ve alçı sıvadan yapılmıştır. Sadece dado seviyesine, yani sadece alt kısımlara kadar mermer ile kaplanmıştır. Üst kısım, mermer altaernatifi olarak kullanılan alçı ile kireç karışımından oluşan bir sıva ile inşa edilmiştir. Ancak, ana kubbe mermerden yapılmıştır. Tac Mahal ile benzer şekilde mermerden yapılmış bir soğan kubbeyle taçlandırılmıştır. Ana kubbe ve minareler, Tac Mahal'den daha küçüktür. Tac Mahal Türbesi tamamıla beyaz mermerden inşa edilirken, Bibi Ka Makbere Türbesi kesme taş yüzeyi bütünüyle alçı ile inşa edilmiştir. Bununda sebebi Bibi Ka Makbere'nin devletin son döneminde ve ekonomik açıdan ciddi sıkıntıların yaşandığı döneme denk gelmiş olması ile açıklanabilir.

Yapının süslemeleri kullanılan motifler açısından Tac Mahal ile benzerliğinden kısmende olsa söz edilebilir. Her iki yapıda da natüralist bitkilerin yoğun olarak kullanıldığı özellikle zambak, nergis, ters lale, gül ve lotus motiflerinin çokça tercih edildiği görülmektedir. Tac Mahal'de bitkisel süslemelerin motif dağarcığının daha geniş olduğu türbe, cami ve mihman hanesinin duvar yüzeylerinin süslemelerinde sıklıkla rastlanılan lale, karanfil, gelincik, hanımeli, sümbül gibi birçok motif burada hiç kullanılmamıştır. Bu motifler niş içerisinde vazodan veya topraktan çıkar şekilde oldukça natüralist biçimde duvar yüzeyine işlenmişlerdir. Tac Mahal'de zeminden 1 metre yüksekliğe kadar yer alan yatay dikdörtgen panolar (dadolar) yoğun bitkisel motiflerle süslü olup, üst kısımları eyvan ve kemerlerin yüzeyleri boş bırakılan sağır nişlerle hareketlendirilirken Bibi Ka Makbere'de tam aksine dadolar sade üst kısımlar sağır nişler yoğun bitkisel motiflerle işlenmiştir. Her iki yapınında ana kubbesi lotus kaideye oturmaktadır ve ana kubbenin iç mekânda göbek kısmında lotus çiçeği motifi işlenmiştir. Her iki yapıda da ters lale-ağlayan gelin çiçeği motifi bulunmaktadır. Dilras Banu Begüm'de doğumundan 1 ay sonra ateșli bir hastalık geçirmiş ve vefat etmiştir. Bilindiği üzere validesi Mümtaz Mahal'de doğum esnasında vefat etmiştir. Bu nedenle bu motiflerin her ikisinin de türbelerinde yer alması tesadüfi değildir. Tac Mahal'de daha yoğun olarak karşılaşılan geometrik süslemelerin burada eserin belli başlı yerlerinde korkuluk şebekelerinde, taç kapının açıklığını örtmek için kullanılan ajurlu şebekelerde (jalilerde) kısmende olsa eyvanın belirli yerlerinde bulunmaktadır. Hat süslemelerin ise yine Tac Mahal'de hem taçkapı yüzeyinde hemde iç mekânda eyvan ve kemerin yazı kuşağında yoğun olarak yer aldığı burada ise neredeyse yok denecek kadar sadece Tac kapıda yer aldığı görülmektedir. Ancak Tac Mahal'de pietra dura- renkli taş kakma tekniği burada görülmezken giriş bina düzenlemesinin iç mekânında renkli sıva boyalara rastlanılmıştır. Ancak ana yapıda yer alan süslemeler oyma ve yüksek kabartma tekniği ile oluşturulmuş Tac Mahal'de beyaz mermer üzerine iken burada kireç benzeri alçı malzemeye uygulanmıştır. Babürlüler döneminde süsleme de renkli taş kakma tekniği bu yapıda görülmemekte onun yerine alçı üzerine rekli sıvalarla oluştrulmuş süslemeler ve alçı kabartma-oyma tekniği ile oluşturulmuş süsleme teknikleri kullanılmıştır.

Babürlüler döneminde giriş bina düzenlemelerine oldukça önem verilmiştir. Yapıların bahçe duvarlarının kenar ortalarında bulunan ve genellikle güney cephede yer alan giriş bina 
düzenlemelerinin yapıya girişi sağlayan ana kapıları olduğu görülmektedir. $\mathrm{Bu}$ giriş bina düzenlemeleri aynı zamanda yapıların en süslü özen gösterilen mekanlarından biri olarak dikkat çekmektedir. Bibi Ka Makbere'de de yapının en süslü yerlerinden birisi hiç şüphesiz güney giriş bina düzenlemesi yani ana giriş kapısıdır. Bu kapı diğer Babürlü örnekleri ile Delhi'deki Hümayun Türbesi'nin ana giriş kapısı, Agra'daki Kırmızı Kale'de bulunan Cihangir Mahal, Fatehur Sikri'deki Bülend Dervaza, Pencap'taki Saray-i Nur Mahal ve son olarak Agra'daki Tac Mahal'in Dervaza-i Ravza kapısı ile benzerlik göstermektedir. Ayrıca Agra'daki İtimat-ud Devle Türbesi'nin duvar süslemeleri ile de burada bulunan süslemeler üslup ve motif özellikleri bakımından oldukça benzer özelliklere sahiptir.

\section{Sonuç}

Hindistan'da kurulan birçok devlet gibi Babürlüler de bu coğrafyanın zengin kültürel ortamından en iyi şekilde yararlanmış bunun yanında kendi köklü mirasları ve güçlü mimari zevkleri ile birlikte önemli mimari eserler ortaya koymayı başarmışlardır. Özellikle türbe mimarisinde anıtsal ölçüde mezar anıtları inşa etmişlerdir. Delhi'deki Hümayun Türbesi ile başlayan bu süreç Evrengabad şehrindeki Bibi Ka Makbere'ye kadar gelişim ve değişim göstererek devam etmiştir. Hümayun Türbesi "Babürlü mimari stilinin gelişiminde olağanüstü bir dönüm noktası" olarak tanımlanmıştır. Babürlü döneminde özellikle türbelerin anıtsal ölçüde inşa edilmiş olması türbelerin, bu dönemin prestij niteliğinde ortaya konulan eserleri olarak değerlenmesini sağlamıştır. Türk-İslam dünyasında türbe mimarisinin en anıtsal ve en özgün örnekleri Babürlüler döneminde inşa edilmiştir.

Babürlü hükümdarlarının türbeleri; Agra, Delhi, Lahor ve Evrengabad gibi devletin başkentlerini oluşturan bu önemli şehirlerde bulunmaktadır. Babürlülerde hanedan kadınlarının türbeleri de eşleri ve çocukları gibi devletin önemli şehirlerinde anıtsal ölçekte inşa edilmişlerdir. Anıtsal türbeler ise daha sonra birçok araştırmacı tarafından belki de yapıldıkları dönemlerde almadıkları kadar eleştirilere ve kıyaslamalara maruz kalmıştır. Bunlardan Evrengzib'in annesi Mümtaz Mahal için Agra şehrinde yapılan Tac Mahal ile eşi Dilras Banu Begüm için Evrengabad'da yapılan Bibi Ka Makbere ne yazık ki sürekli mukayese edilmiştir. Ancak her iki yapıda dönemin önemli kadın sultanlarına yapılmış ve döneminde olduğu gibi çağımızda da bulundukları şehrin önemli mimari eserleri olarak varlıklarını sürdürmektedir. Dilras Banu Begüm Türbesi bölgede; yaygın olarak kullanılan Rabia-ud Devrani Türbesi, Bibi Ka Makbere isimlendirmelerinin yanında bu benzerlik yakıştırmaları sebebiyle Mini Tac Mahal ve Dekkan'ın Tacı şeklinde de adlandırılmıştır.

Bibi Ka Makbere'nin mimarı Ataullah Tac Mahal'in yapım ustalarından Ahmet Lahori'nin oğludur (Michell ve Zebrowski, 2008: 11) bu ilişkide aslında iki mimarinin bu kadar benzetilmesinin şaşırtıcı olmaması gerektiğinin bir kanıtıdır.

Türbeyi Tac Mahal'in bir kopyası değil de Babürlü döneminde türbe mimarisinin bir gelişim evresi, Tac Mahal'in farklı bir varyasyonu olarak değerlendirmek daha doğru olacaktır. Hatta Tac Mahal, türbenin prototipini oluşturmaktadır. Bununla birlikte türbe sadece Tac Mahal'e benzerlik göstermemekte mimari olarak Hümayun Türbesi ile de oldukça yakın benzerliklere sahip olduğu görülmektedir. Bibi Ka Makbere Tac Mahal'in bir kopyası şeklindeki yaygın yanlış algısının aslında Tac Mahal'in tesirinde kalmamasının mümkün olmadığı ile ilişkilendirilmesi daha sağlıklı ve yerinde olacaktır. Bunun yanında yapı; plan ve mimarisi ile genel Babürlü özelliklerine sahip olmasına rağmen yapının malzemesi, oran-orantı ve tasarımı bakımından önemli ölçüde farklılıklara sahiptir.

Türbenin mezar yapısı ise hiçbir türbe örneği ile kıyaslanamayacak kadar üniktir. Diğer Babülü hanedan türbelerinde girişin bulunduğu ziyaretgâhın yer aldığı zemin katta sembolik sanduka yer alır ve bu zemin katın tam hizasında alt katta asıl mezar sandukasının yer aldığı cenazelik katı bulunur. Ancak bu türbede tek bir mezar sandukası bulunmaktadır. Zemin katta ana mekânın merkezinde yer alması gereken sembolik sandukanın bulunduğu alan açık bırakılarak buradan aşağ 1 doğru bakıldığında ana mekânın tam hizasında alt katta yer alan asıl mezar sandukası görülmektedir. 
Türbeyi diğer Babürlü ve Türk-İslam türbe örneklerinden ayıran kısmı da ziyaretçilerin zemin kattan aşağı doğru baktıklarında asıl mezar sandukasını görüyor olmalarıdır.

Sonuç olarak türbe Babürlü döneminin sona ermesine yakın bir tarihte devletin kısıtll imkânlarına rağmen hem malzeme hem de mimari ve süslemeleri ile oldukça başarılı bir yapıdır. Yapının bölgenin iklim şartlarına rağmen günümüzde hala dimdik ayakta kalmasına bakıldığında malzemenin dönem şartlarına göre yine iyi kalitede inșa edildiğini göstermektedir. Bibi Ka Makbere Babürlü mimari estetiğinde bir dönüm noktasıdır. Mimari özellikleri ve planı bakımından değerlendirildiğinde orantısız olduğu düşünülse de yapı oldukça ünik, süsleme özellikleri ve tasarımı açısından da bir o kadar zarif ve estetiktir.

\section{Kaynakça}

Asher, C. (1992). Architecture of Mughal India, Vol.1.4. Cambridge: The New Cambridge History of İndia.

Fergusson, J. (1910). History Of Indian And Eastern Architecture Vol I. London: John Murray.

Galib, M. ve Gömeç S. Y. (2013). Hindistan'da Türkler. Ankara: Berikan Yayınevi.

Michell, G. (2007). The Majesty of Mughal Decoratıon The Art And Architecture of Islamic India. London: Thames\&Hudson.

Michell, G. ve Zebrowski, M. (2008). Architecture and Art of the Deccan Sultanates. United Kingdom: Cambridge History of India (Cambridge Histories Online (C) Cambridge University Press).

Önkal, H. (2015). Anadolu Selçuklu Türbeleri. Ankara: Atatürk Kültür, Dil ve Tarih Yüksek Kurumu.

Özler, F. (2018). Delhi ve Agra'daki Babürlü Türbelerinde Mimari Süsleme (1557-1658). Yayınlanmamış Doktora Tezi, Erciyes Üniversitesi Sosyal Bilimler Enstitüsü, Kayseri.

Palalı, S. (2013). Orta Asyalı Bir Figür Olarak Sebz Burc: Mimari Tasarımı, Süsleme Programı ve Tarihlendirme Sorunu. Dokuz Eylül Üniversitesi İlahiyat Fakültesi Dergisi, 153-188.

Parodi, L. E. (1988). The Bibi-ka Maqbara in Aurangabad A Landmark of Mughal Power in the Deccan? Istituto Italiano per l'Africa e l'Oriente (IsIAO),East and West, Vol. 48, No. 3/4, 349-383.

Robinson, F. (2007). The Mughal Emperors and Islamic Dynasties of India, Iran and Central Asia. London: Thames\&Hudson.

TDV. (1988-2013). Türkiye Diyanet Vakfi İslam Ansiklopedisi. Evrengzib. TDV İslâm Araştırmaları Merkezi Elektronik Ansiklopedi. 